\title{
WPS3866
}

\section{On Defining and Measuring the Informal Sector}

\author{
Andrew Henley $\dagger$ \\ G. Reza Arabsheibani† \\ Francisco G. Carneiro*
}

Keywords: Informal Employment, Social Protection, Self-Employment, Entrepreneurship

JEL Classification: J21, J42

World Bank Policy Research Working Paper 3866, March 2006

The Policy Research Working Paper Series disseminates the findings of work in progress to encourage the exchange of ideas about development issues. An objective of the series is to get the findings out quickly, even if the presentations are less than fully polished. The papers carry the names of the authors and should be cited accordingly. The findings, interpretations, and conclusions expressed in this paper are entirely those of the authors. They do not necessarily represent the view of the World Bank, its Executive Directors, or the countries they represent. Policy Research Working Papers are available online at http://econ.worldbank.org.

† School of Business and Economics, University of Wales Swansea, UK

* The World Bank - Poverty Reduction and Economic Management (PREM). 


\begin{abstract}
A range of alternative empirical definitions of informal activity have been employed in the literature. Choice of definition is often dictated by data availability. Different definitions may imply very different conceptual understandings of informality. In this paper, Henley, Arabsheibani, and Carneiro investigate the degree of congruence between three definitions of informality based on employment contract registration, social security protection and the characteristics of the employer and employment using Brazilian household survey data for the period 1992 to 2001. 64\% of the economically active are informal according to at least one definition, but only $40 \%$ are informal according to all three. Steady compositional changes have been taking place among informal workers, conditional on definition. The econometric analysis undertaken by the authors reveals that the conditional impact of particular factors (demographic, educational attainment, family circumstances) on the likelihood of informality varies considerably from one definition to another. Their results suggest growing heterogeneity within the informal sector. Therefore, the authors argue that informal activity may be as much associated with entrepreneurial dynamism as with any desire to avoid costly contract registration and social protection. However, this paper confirms that there is no a priori reason for entrepreneurial activity to be unprotected. Consequently definitions of informality based on occupation and employer size seem the most arbitrary in practice even if conceptually wellfounded.
\end{abstract}




\section{On Defining and Measuring the Informal Sector}

\section{Introduction}

The growth and scale of informal employment in many developing countries has been traditionally attributed to the displacement of workers into insecure forms of labor market attachment as the only feasible alternative to unemployment (Fields, 1975; Mazumdar, 1976). ${ }^{1}$ More recently a number of authors (Pradhan and van Soest, 1995, 1997; Cohen and House, 1996; Marcoullier et al., 1997; Maloney, 1999; Saavedra and Chong, 1999; Gong and van Soest, 2002) question this interpretation of informality, by calling into doubt the idea that the existence of informal and formal sectors is a manifestation of "dualism" in the labor market. A further strand of research has highlighted the dynamic “micro-entrepreneurial” nature of informal economic activity (Cunningham and Maloney, 2001; Maloney, 2004; Pisani and Pagan, 2004). This view of informality is well-established and can be traced back to the work of Hart (1972). A final view (and one which we do not address in the present paper) concerns the relationship between informality and illegal or tax-evading activity (see Gerxhani, 2004, and Loayza et al., 2005). ${ }^{2}$ Each of these alternative views shares in common the idea that informal activity may be freely chosen by some workers. These individuals either perceive state social protection to be poor "value for money" or do not wish to have the conditions of their employment relationship (such as hours of work) restricted by tight state labor market regulation. Alternatively they may be attracted by the prospective job satisfaction or income stream associated with a successful transition into entrepreneurship, or may perceive the relative benefits of illegal or unregistered activity to outweigh the risks of detection. 
The size of the informal sector is of particular interest to economic policy makers concerned to promote the development of a micro-entrepreneurial sector. This concern arises because of its perceived contribution to dynamic economic efficiency, possibly as a response to growing competitive pressures brought about by trade liberalization. On the other hand policy makers may be concerned that significant numbers, perhaps even a majority of workers in developing countries, have little or no social security provision. This means that they have little on which to fall back in the event of illness, unemployment or old age, beyond personal wealth and extended family support. A narrower but nevertheless important concern may be to reduce informality in order to widen the base of direct taxation.

This discussion of alternative perspectives on informality brings into sharp focus the question of the most appropriate way to define and measure the informal sector. This is a question which has attracted little or no detailed attention in the literature. The purpose of the present paper is to attempt to redress this. This lack of attention may arise from the paucity of data on a sector which by its nature is problematic to define. Thus researchers tend to fall back on the pragmatic and judicial use of data on employment status and sectoral affiliation. There is little discussion of the sensitivity of any conclusions drawn to issues of measurement and definition. An implicit assumption is that international comparisons of the scale of informality, which may be based on very different empirical definitions, are valid. Over the last 20 years or so the growing availability of household and living standards surveys has improved the evidence base for many developing economies. However such surveys are typically not sufficiently rich to permit an evaluation of alternative definitions of informality. 
Household survey data available for Brazil is a notable exception to this. Large scale annual household surveys contain detailed information on individual household member economic status (the Pesquisa Nacional por Amostra de Domicílios or PNAD). They permit some comparison of alternative informality definitions. Firstly individual informality can be examined at the level of employer compliance with state labor market regulation through the possession of a registered labor contract (signed labor card). Secondly informality can be examined at the level of individual social protection coverage, through membership of a social security institute. Finally informality can be examined, as it is in many studies for which information on contract registration and social protection coverage is non-existent, by addressing the scale of micro-entrepreneurship activity. In practice this means an examination of individual employment status (type of employment or self-employment) combined with information, if employed or an employer, on the sector and scale of the business activity.

A comparative descriptive investigation of the sets of individuals defined as informal according to these different definitions reveals some substantial similarities, such as in demographic and educational status. However, a multivariate (probit) analysis reveals that some characteristics are more strongly associated with one measure of informality than another. For example, educational attainment is far more strongly associated with social security institute membership, and with informality defined according to employment status and activity than it is with the measure of informality based on compliance with labor regulation. On the other hand social security institute membership appears to be less strongly associated with the demographic and informal status of others within the household. 
So the main conclusion to be drawn from this research is that the precise definition of informality does matter. It cannot be assumed that alternative definitions are broadly consistent, and that the conclusions drawn from any detailed analysis or modeling of informality will be robust to definitional choice. This is particularly important given recent developments in the debate on the subject. Any particular choice of definition or measurement may be conditioned by a priori perspectives or hypotheses about the nature and role of the informal sector.

The remainder of the paper is structured as follows. Section 2 provides a more detailed discussion of the existing literature and in particular on the way in which informality has been defined and measured. Section 3 discusses the Brazilian data source used and the different measures of informality which are analyzed. Section 4 provides some descriptive analysis and discussion of these measures. Section 5 documents a multivariate analysis to investigate commonalities and differences in the way in which the different indicators of informality are associated with demographic, employment and household characteristics. Section 6 provides a concluding discussion.

\section{Defining Informality}

The practice of defining informality in terms of the economic status of the individual (self-employed or own-account worker, domestic worker, small scale employer etc.) in conjunction with the characteristics of the employer (small scale, no collective bargaining etc.) is well-established in the literature. A substantial number of early analyses of informality simply 
assume that the informal sector corresponds to sole-traders (own account workers) and those in small or micro enterprises. "Small” or "micro" is defined arbitrarily and may depend on questionnaire design. For example, from recent research which makes use of such a definition of informality, Prahan and van Soest $(1995,1997)$ and Maloney (1999) use a definition of fewer than six employees for Bolivia and Mexico respectively; Funkhouser (1996) uses fewer than five employees for an analysis of five Central American economies; Marcoullier et al. (1997) use fewer than six for Mexico and Peru; Cohen and House (1996) use fewer than 20 for Sudan; Livingstone (1991) uses fewer than 10 for Kenya. Galli and Kucera (2004) undertake an international comparative study across 14 Latin America countries. They employ a definition adopted by the ILO based on employees in firms of either fewer than 5 or 10 employees (depending on the country). Comparability is compromised because of limited detailed information on the size distribution of firms.

Where authors have been particularly concerned to highlight the role of informality in promoting entrepreneurship this definitional approach has been explicitly preferred over alternatives. However the attractiveness of defining informality as equivalent to the "entrepreneurial” sector side-steps the important conceptual question of how large does an establishment have to become for it to cease to be part of the dynamic, entrepreneurial sector. Some authors have introduced a further distinction into the definition of the informal sector by including some industrial activities and excluding others (most notably professional service activities). A shortcoming of this approach is that it excludes the possibility, even if it is an unlikely one, that some employees in small establishments may have contracts of employment which conform to labor market regulations and may contribute to social insurance schemes. It 
also excludes the possibility that some large private sector employers may not provide registered employment contracts or encourage employee contributions to social insurance schemes. Similar objections might apply to domestic and temporary workers who are often entirely classified as informal.

The economic significance attached to whether an employment relationship conforms to state labor contracting regulations depends on the degree to which those regulations impart inflexibility in the extent to which both parties can tailor the terms and conditions of employment to their best advantage. So, for example, if regulations permit flexible hours of work with no effective upper constraint then the economic impact of signing a formal contract compared to working informally may be less, and the rationality for participating in the informal sector reduced. The existence of significant lay-off costs if a formal contract is terminated may be one of the main factors pushing employers towards offering informal employment (see World Bank, 2002 on the case of Brazil).

The argument that both employees and employers may prefer to enter into either unregistered or registered employment relationships will hinge on the balance of the advantages and disadvantages. This is the central argument behind recent work (such as Maloney 2004) which rejects the traditional view that the informal sector is a labor market segment populated by displaced workers queuing for good jobs in the rationed formal sector. Perhaps the most persuasive evidence in support of this is in Maloney (1999). He uses Mexican panel data to examine between-sector and within-sector transitions. The definition of informality used in this research is based on establishment size rather than contract status. However no evidence is found 
to support the proposition that those newly entering informal employment are more likely to be young, displaced workers waiting for better jobs. So contract status should provide a good discriminator for informal status if the allocation of workers to the informal sector is governed by a free assessment of the costs and benefits of labor contract registration. Informality should therefore be defined not according to the nature of the job or the employer but according to the worker's legal status. But in practice the informal sector may exist for a complicated mix of reasons. Some workers may choose to be there because jobs are more flexible or because selfemployment is more attractive whereas others may be displaced involuntarily into the sector.

The practical problem with defining informality in terms of illegal employment is that data may simply not exist on contract status. This is particularly so if the employee does not know for certain whether the employer is conforming to employment regulations, something that might be more likely in the case of temporary workers. For the self-employed or for own-account agricultural workers such a definition may have no relevance since an own-account worker cannot contract with themselves. In some countries, of which Brazil is a notable example, employers are required to indicate to workers that the employment relationship is legally registered. So a third party such as a statistical agency can establish this with a reasonable degree of accuracy. It therefore follows that the informal sector in Brazil has attracted particular attention from researchers.

Where information on contract status is not available or relevant, the principal alternative definition of informality is one defined by social protection status. The paper that is widely regarded as the seminal empirical study of the informal sector (Merrick, 1976) employs this 
definition. Merrick’s study is of the urban labor market of Belo Horizonte in central eastern Brazil. For employed workers informality is defined by the lack of membership of a social security institute. Subsequent work which has adopted the criterion of no social protection or non-payment of social security taxes for distinguishing informal employees includes Portes et al. (1986), Marcouiller et al. (1997), Maloney (1999) and Saavedra and Chong (1999). Absence of social protection is regarded as an important indicator of informality, focusing attention on the potential costs of informality to employees in the event of adverse economic circumstances. The consequences of informality so defined may depend on the economic position of the individual within the household: that is whether they are the main or secondary earner. It may also depend on or the social protection status of other household members. This definition also focuses attention on the inefficiency of social protection systems as a possible driver of the growth in informality. However typical household or individual surveys used to investigate informality may not provide information on the social security status of the self-employed or small employer. So studies often rely on a "hybrid” definition of informality in which employees are classified according to social security status. Own-account workers are classified as entirely informal and employers classified according to either or both the size of their business (number of employees) or the activity of the business.

A small number of previous studies have investigated the sensitivity of measured rates of informality to choice of definition. Marcouiller et al. (1997) compare the size of the informal sectors in El Salvador, Peru and Mexico using definitions based on firm-size ${ }^{3}$ and on nonpayment of social security taxes. The latter definition produces a considerably higher estimate of the size of the informal sector (43.2\% compared to $30.8 \%$ of workers in the case of Mexico in 
1990). However, depending on country, between 89 and 97\% of the self-employed and smallfirm employees do not pay social security taxes. This definition is preferred for the econometric analysis of the wage differential between the two sectors because it is more comprehensive. Saavedra and Chong (1999) similarly find the informal sector to be larger when defined according to social security coverage rather than firm size (54.8\% compared to 53.3\% in Peru in 1995). Although this difference is not as great as in the Marcouiller et al. study, the two definitions in this case display substantially different trend and cyclical behavior. The authors take the view that the social security definition is more useful because it shows informality falling with economic growth around a counter-cyclical movement. They use this definition in subsequent analysis of the earnings differential between the two sectors.

A third more recent paper, Gong et al. (2000), examines the scale of informality in Mexico over the period 1992 to 1995 using various definitions. Defining informality according to job type (self-employed plus piece-rate workers) provides an estimate of $37.6 \%$ for the rate of informality. Defining informality according to firm size (less than six employees) provides an estimate of $30.4 \% .89 \%$ of informal workers according to either definition have no social security coverage, whereas only $26.2 \%$ and $19.2 \%$ of those classified as formal under the job type and firm size definitions respectively had no social security coverage. In subsequent econometric work on sector transitions (Gong and van Soest, 2002) the job type definition is preferred. ${ }^{4}$ These findings tend to suggest that there is varying correspondence between alternative definitions of informality. It would therefore be surprising if econometric analyses modeling allocation between sectors or sector earnings differentials were robust to choice of definition. 


\section{Measuring Informality in Brazil}

Many commentators express a belief that the informal sector in Brazil is large and growing, despite trade liberalization and successful macroeconomic stabilization over the last 15 years. For example, Carneiro (1997) reports that, although in the late 1980s the Brazilian economy appeared to stagnate, unemployment rates remained low and total employment (formal and informal) continued expanding. In 1988, prior to trade liberalization and at a time of chronic price instability, the Brazilian statistical agency (IBGE) estimated that 13\% of GDP was generated in the informal or unregistered economy. Within the service economy this proportion was estimated as high as 30\%, suggesting that the overall estimate may well have been conservative (Carneiro, 1997).

The achievement of macroeconomic stability in Brazil that followed the successful adoption of the Plano Real in 1994 might have removed some of the pressure for economic activity to migrate into the informal sector. On the other hand trade liberalization in the early 1990s increased competitive pressures in the tradable sectors of the economy. But recent research finds little or no relationship in Brazil between trade liberalization and informal employment, defined according to labor contract status (Goldberg and Pavcnik, 2003). Furthermore constitutional reform in 1988 may have simultaneously decreased flexibility in the formal labor market (Barros and Corseuil, 2001). So the emerging pattern of development in the informal sector may be complex. 
Regulation of the labor market in Brazil can be traced back to the enactment of the Labor Code of 1943. This mandates official registration of all contracts of employment through the requirement of employers to provide a signed labor card (“carteira de trabalho assinada”). The card contains a statement of the terms of employment to all employees. Registration of a labor contract confers a legal entitlement to a range of contract terms including a maximum working week (currently 44 hours), paid vacations, maternity leave, due notice of dismissal (proportional to seniority) $)^{5}$, a minimum overtime premium and an entitlement to compensation in the event of a non-justified dismissal. Dismissal compensation is paid from the Fundo de Garantia por Tempo de Serviço (FGTS) accumulated by every worker with a signed labor card. The employer contributes an amount equivalent to $8 \%$ of the employee's current monthly wage. The employee receives a penalty of $40 \%$ of the employer's cumulative contribution in the event of dismissal without just cause. This penalty was increased from 10\% by the 1988 Constitution. As Barros and Corseuil (2001) note the effect of the change was to reduce the length of tenure needed to accumulate a compensation amount equal to one month’s salary from at least 10 years to only two and a half years. At face value this would appear to amount to a substantial increase in employer firing costs, although in practice it creates the potential for collusion between employers and employees to register voluntary quits as dismissals. Thus it creates an incentive to quit on the part of employees. Barros and Corseuil (2001) and Camargo (2002) cite evidence in support of this. In short there may be a strong disincentive for employers to register contracts, but, once registered, employers and employees face incentives which increase turnover.

Social protection beyond dismissal compensation in Brazil is provided through individual employee membership of a social security institute (Instituto de Previdência). Protected workers 
pay monthly contributions on a graduated scale up to a ceiling of 11 per cent, with employers contributing a further $20 \%$ of payroll. Membership of an institute provides defined benefit pension provision (up to an upper ceiling), permanent disability benefits and life insurance (survivor) benefits. Workers without social security institute membership qualify for a meager flat rate old age pension equal to the minimum wage.

Our investigation of informality draws on detailed information contained with the Brazilian household survey (PNAD). From 1992 the consistent questionnaire structure adopted by the survey allows separate identification of contract registration (labor card) and social protection across an individual's main and supplementary jobs, alongside detailed information on the type of employment and the size and activity of the business. Surveys were conducted annually with the exception of 1994 (because of austerity associated with the introduction of the Plano Real) and 2000 (the year of the decennial census).

Table 1 reports summary information on economic activity in main employment for all workers aged between 18 and 65 for each available year. All descriptive analysis makes use of individual sample weights provided by IBGE. In any year just over half of the economically active are engaged in paid employment. This proportion seems quite stable although there is some evidence of an upturn in the proportion towards the very end of the period. However the proportion of public sector workers, who by definition have registered contracts, falls from $27.4 \%$ of employees in 1992 to $23.6 \%$ in 2001 . The next largest group are the self-employed (own-account workers), comprising almost of quarter of the economically active. A further four percent are entrepreneurs employing others. There is some slight evidence that employers as a 
proportion of the total have risen over the period, but no discernable trend in the proportion of the self-employed. A further 1.1\% of the overall total, in 1992, are individuals whose main status is as an employee, but have self-employed or employer status in a second activity. This figure drops slightly to $0.95 \%$ in 2001 . Thus in $199228.4 \%$ of economically active adults could be regarded as engaged in some broad form of entrepreneurial activity, either as main or secondary activity. This total remains virtually unchanged at $28.3 \%$ in 2001 . So overall these data appear to offer little support for rising entrepreneurialism.

The fastest growing group as a proportion of the total is domestic workers, rising from $6.2 \%$ in 1992 to $7.8 \%$ in 2001 . This is an employment group traditionally associated with informality, although as we shall see there should be no automatic presumption that domestic workers are unregistered and unprotected. Increasing employment of domestic staff may reflect rising standards of living in Brazil, particularly amongst upper and middle earners. The data allow the identification of three further categories of employment, each of which may be regarded as informal: non-remunerated employment (typically in a family business), subsistence agricultural workers and temporary workers. As a proportion of the total each if these is small. For each proportion there is some evidence of a downward trend.

In order to assess the possible size of the informal sector we adopt three different definitions to distinguish formality and informality.

A (contract status): a worker is defined as formal is they have a signed labor card in any employment. Through its questionnaire routing the PNAD regards all public sector employees as 
having signed labor cards. Those who are self-employed or employers in their main occupation are classified as formal if they have a signed labor card from another paid second job.

B (social security status): a worker is defined as formal if they make contributions to a social security institute (federal, state or municipal) in respect of any employment. The PNAD asks all workers regardless of economic status or sector if they make social security contributions.

C (formal activity): a worker is defined as formal if they are employed in an establishment of more than five employees. The self-employed and employers are defined as formal if their occupation is "creative and technical” or "administrative” (to capture "professional” activities). All domestic, non-remunerated, subsistence and temporary workers are defined as informal, along with all the self-employed and employers in occupations other than "creative and technical” and "administrative".

\section{Variation in Informality in Brazil}

Table 2 details the proportions of workers classified as informal under each definition according to economic status. Definition A based on contract status provides the largest estimate of the size of informal employment, at between 56 and 58 per cent of all workers. The smallest estimate at around $50 \%$ is provided by definition C, in which workers are categorized according to establishment size and occupation. Definition B based on social security status provides an estimate of informal employment at just over $50 \%$. There is no discernable trend in any of the three definitions. 
Once the data are sub-divided by economic status, wider variation between the definitions is apparent. Turning first to employees, definition C continues to provide the smallest estimate of informal employment at below 20\%, but definition B (social security membership) now provides the largest estimate at between 24 and $28 \%$. For all three definitions there is some evidence of an upward trend in informality. This is most pronounced for definition C, where informality rises from $12.8 \%$ in 1993 to $16.6 \%$ in 2001.

For the self-employed only those whose main job is as a registered employee are recorded as formal under definition A, and only those who business activity falls under the two professional occupational categories are classified as formal under definition C. Informal selfemployment activity under definition C is falling slightly. Informality declines from $95.5 \%$ to 93.0\% over the period. Under definition B (no social security protection) less than $80 \%$ of the self-employed are informal in 1992. Here there is a clear upward trend. The proportion rises to over $84 \%$ by 2001 .

For employers only those few with registered main jobs are classified as formal under definition A. So rates of informality defined by lack of a signed labor card are very high. One third of employers have no social security protection in 1992. This proportion remains at the same level until 1997 when it starts to rise quickly. Under definition C very few employers are classified as informal. In fact up to 1993 the occupational classification defines all employers as “creative and technical” or "administrative”. From 1997 onwards the informal proportion starts to rise. The remaining four groups in Table 2 are all entirely classified as informal under 
definition C. A significant minority of domestic workers and, to a lesser extent, temporary workers have registered contracts and/or make social security payments. For both groups the proportions which are defined as informal are falling. The proportion of domestic workers with a no signed labor card falls from 79 percent in 1992 to 72 per cent in 2001, and those with no social security coverage from 77 percent to 69 percent.

In summary Table 2 reveals some significant differences both between the different definitions we have constructed, and between the experiences of different types of workers. For employees the level of informality is stable, despite the relative decline of public sector employment. For entrepreneurial groups (the self-employed and employers) informality if defined by social security status is increasing. However, if informality is defined according to the nature of the activity, it is falling amongst the self-employed. Informality amongst domestic and temporary workers is also falling.

The other feature in Table 2 is that there is incomplete overlap between the different definitions, and for some groups the overlap may be quite limited. In particular the definitions of informality based on contract and social security status (A and B) may distinguish very different groups of workers compared to the definition based on activity (definition C). Table 3 reports pairwise correlation coefficients for the three measures. Definitions A and B have a correlation of around 0.8 suggesting a reasonably high, although far from complete, correspondence between the two measures. Definition C has a lower correlation with the other two measures, and particularly with social security status. Figures 1 and 2 explore this point further by providing Venn diagrams to show the correspondence of the three measures across the full sample of the 
economically active for 1992 and 2001. In both years just under 40 percent of the sample can be defined as informal on all three definitions. Just over 36 percent of the sample in both years can be classified as formal on all three definitions. A total of 13.4\% of the sample in 1992 and $12.9 \%$ in 2001 can be classified as informal on any two of the three definitions. In particular there is a significant proportion of workers classified as informal on the basis of having no signed labor card and no social security coverage but who fall into the formal category under definition C. A total of 9.9\% of the sample in 1992 and $11.0 \%$ in 2001 fall into one of the definitions of informality but neither of the other two. The largest element of this group, particularly in 2001, is those who are classified as informal on the basis of activity but have a signed labor card and social protection. Domestic and temporary workers form a significant element of this group.

Table 4 reveals the different position of men and women. Across all three definitions informality is increasing amongst men and falling amongst women. The upward trend for men is most pronounced for definition C, to the extent that by 2001 the estimate of male informality on the basis of activity is within 1.2 percentage points of the estimate on the basis of social security coverage. For women the decline in informality is steepest for definition B. There is very little trend in female informality defined by activity. Notice also that there is a difference in the orderings of the estimates for men and for women. Male informality is highest when defined by contract status (no signed labor card) and lowest when defined by activity. Female informality is highest when defined by contract status at the beginning of the period but by 2001 is highest when defined by activity. It is lowest when defined by social security status. So Brazil has had enjoyed some success in improving social security participation amongst women, but this has been partially at the expense of the worsening position of men. There has been a change in the 
composition of informal activity towards men, partially offset by women moving into formal activity, as well as a shift in the composition of those without registered contracts towards men. This last shift has been to such an extent that by 2001 men are more likely than women not to have a registered contract.

Table 5 reveals that informality is very strongly associated with educational attainment. Rates of over $80 \%$ are observed for the illiterate. These fall to around a quarter for college graduates. Rates of informality are rising amongst the lower level groups (illiterate and elementary), but against a background of these groups falling fast as a proportion of the total active population. Informality is rising quickly amongst secondary school and college graduates on all three definitions. The reason why informality is rising for many educational sub-groups, although stable for the population as a whole, is because of the relatively stable level of informality amongst the illiterate and elementary groups who are declining rapidly as a proportion of the population. Absolute numbers of uneducated or poorly educated informal workers are falling fast in Brazil. This overall pattern is common to all three informality definitions. However there are differences in the levels of informality for particular educational groups according to definition. Rates of informality amongst the illiterate are lower for definition C than for A and B. On the other hand rates of informality, defined by no signed labor card, are higher amongst secondary and college educated groups than for the other two definitions.

Rates of informality in establishments of different sizes according to each definition are given in Table 6. By definition those working in larger establishments (6 or more employees) are classified as formal according to definition C. Amongst sole-traders informality has risen 
significantly when defined by social security institute membership (mirroring the picture in Table 2), but is stable for the other two definitions. For those in very small establishments, that is two or 3 to 5 employees, informality has fallen slightly according to definition A but risen according to definition B and, in particular, definition C. Rates of informality defined by contract or social security status have also risen significantly in larger (11+ employee) establishments. These larger establishments employ almost 50\% of the workforce. Informality is high amongst those who do not know their establishment size. Lack of information here may correlate with poor educational attainment. In summary Table 7 suggests that informality is increasing in large establishments whereas (in terms of contract status) it is falling in the smallest establishments, and is stable in the middle (establishments with 6 to 10 employees).

Table 7 describes rates of informality according to occupation. The occupational breakdown is a broad classification of eight sectors. Rates of informality vary considerably by occupational groups. Informality is high in agricultural, retailing and distribution occupations, and in domestic, personal and catering services groups. It is low in the creative and technical, administrative, and transport and communications groups. Alternative definitions of informality provide in some cases very different pictures of informality by occupational group. Since the self-employed in the creative and technical group are defined according to definition $\mathrm{C}$ as formal, then rates of informality according to this definition are very low. Yet it is apparent that numbers without signed labor cards or social security institute membership are much higher and rising over time. In retailing and distribution informality defined according to social security protection is significantly lower than according to the other two definitions. To a lesser extent the same holds for transport and communications occupations. In this sector informality is rising fast 
according to all three definitions. Informality as measured by definitions A and B is falling in domestic, personal and catering occupations. It is also falling in retailing and distribution. Both of these sectors are growing as a proportion of total employment.

\section{Multivariate analysis of factors associated with informality}

Although we have been able to point to differences and similarities between key demographic variables and different definitions of informality, we can say nothing so far about any conditional association between these. This section presents estimates of the marginal effects of different potential influences on the likelihood of informality obtained from probit regressions. The specification of each regression includes individual demographic information, information on the geographical situation of the individual, information on the nature of the employment and information on the economic status of the remainder of the individual's family. Included under the heading of demographic information are a quadratic function of the individual's age and binary indicators for gender and ethnicity (reference category: white male). Indicators of illiteracy and educational attainment are also included (reference category: education to elementary level). ${ }^{6}$ Two aspects of geographical situation are included. The first is a set of broad regional indicators, defined so that the heavily urbanized and industrialized region of the South East is the reference category. Given that some previous research identifies informality with urbanization, the second is a binary indicator for residence in an urban location. The urban indicator is a variable derived by the IBGE statistical agency from household address records and corresponds to residence in cities, towns and so-called isolated urban areas. 
Three aspects of the nature of the individual's employment are included. A binary indicator of unionization is included to capture a likely association between collective representation and formality. It is important to uncover the extent to which definitions of informality based on contract and social security status identify individuals predominantly in small establishments. So information on the size of the establishment, in the form of a binary indicator for greater than 11 employees is included for regressions to explain definitions A and B. (Since definition C is partly based on establishment size it is not appropriate to include it as an explanatory factor.) Indicators of broad occupational grouping are included to assess the extent to which there may be certain occupational sectors in which employment tends inherently to be less formal. The reference occupation here is a residual category denoted "other". It includes a range of occupations in the extractive and public (including defense) sectors.

Turning to indicators of the economic status of the rest of the family, the first inclusion is a binary indicator for the informal status of the individual's spouse conditional on being married and economically active. Spousal informality is defined throughout according to definition A for consistently and comparability. We hold no prior hypothesis here. Having a spouse without a registered contract may create a greater incentive to acquire the protection of a formal sector job. On the other hand informal workers may be simply more likely, as a result of a marriage matching process, to have informal sector spouses. For the same reasons the total number of formal employees in the family (i.e. with signed labor cards) is included, as well as the total number of self-employed in the family. The presence of dependents within the family may also influence individual employment decisions or options. So the totals of elderly (i.e. aged 65 and over) and children in the family are included. Finally other family earnings per head is included. 
This is an indicator of the extent to which the individual workers may rely on income generated elsewhere in the family as an alternative to social protection.

Table 8 reports estimated marginal effects for each year for definition A (no signed labor card). Threshold levels of statistical significance are indicated - full results are available on request. In general most of the explanatory factors included in the regressions attract statistical significance although there is considerable variation in the importance of particular associations, as indicated by the size of the marginal effects. There is a U-shaped relationship between informality and age. The age at which an individual is most likely to have a signed labor card is in their late 20s, other things equal. Women are 5 percentage points less likely to be informal than men, other things equal. Indigenous and Asian ethnic groups appear more likely to be informal than whites, and blacks less so. However those of mixed race (the largest non-white group) are no more or less likely than whites to be informal. Illiteracy is positively associated with informality, but only by 6 to 9 percentage points. The marginal effects for the various educational attainment levels do not suggest any qualitatively strong relationship between schooling and informal status. In particular college (first degree) graduates appear no less likely to have a signed labor card than those with only basic schooling, other things equal.

The reported marginal effects for the four regions show that informality is higher outside the South East, and in particular in the North and the North East. However these regional differences appear to be in decline. Urban residents are only slightly less likely to be informal than those in rural areas. On the basis of definition A there is no reason to view informality as a predominantly urban phenomenon. The lack of a signed contract is strongly associated with 
absence of union representation and with small establishment size. But there is some evidence in the results to suggest that the association with small establishments is also in decline. There is also a strong occupational pattern to the lack of a signed contract, although once again these effects are declining quite significantly over time. Informality as defined here is strongest amongst agricultural, production, construction, retailing and distribution occupations.

Informal status defined on the basis of contract appears to be weakly complementary with informality elsewhere in the family. If workers have a spouse who is working without a signed labor card then they are 2 to 4 percentage points more likely to be informal themselves. Similarly an increase in the number of formal workers in the family as a whole is associated with a lower likelihood of informality, at a similar order of magnitude. Self-employment activity elsewhere in the family is strongly positively associated with informal contract status. The presence of elderly and children slightly but statistically significantly reduces the likelihood of informal contract status. Higher other family earnings are negatively associated with informality in 1992, but by 1995 are positively associated and remain so until the end of the period in question. There is some evidence that this positive association grows in size.

Table 9 reports exactly the same regression specifications for the definition B (no social protection). There are some pronounced differences between these results and those reported in Table 8. The age at which an individual worker is least likely to be informal now increases to the early to mid 40s. Women are now more likely to be informal. Mixed race individuals are significantly more likely than whites to be informal, although the marginal effect indicates that the difference is only between 2 and 4 percentage points. There is now a much stronger negative 
association between higher educational status and informality. This negative association appears to become stronger towards the end of the period. Urban residents are less likely to be informal and the marginal effects are at least twice as large as those in Table 8. Union status and employment in a large establishment remain quantitatively very important, although the negative marginal effect for being with a large employer falls from over 60 percentage points to around 46-47 percentage points. By 2001 the patterns of occupational coefficients are different from those in Table 8. Although agricultural occupations remain far more likely to be informal, the strong positive effects seen for production, construction, retail, distribution and communications are diminished. Under definition B those in administrative occupations are significantly and quantitatively less likely to be informal. Turning to the variables describing the economic status of the family, we observe that the size of the positive relationship with the number of selfemployed is the family falls substantially and that the associations with family dependents and other family income cease to be significant.

Table 10 reports the results for the definition C based on establishment size and activity. Age remains significantly associated with informality - the age at which informality is least likely is around 30 years, closer to that for definition A than for B. Being female is positively associated with informality - women are 4 to 6 percentage points more likely to be in an informal activity. There is however virtually no significant association between ethnicity and this definition of informality. The association between educational attainment and this definition of informality is, from the pattern of the marginal effects, the most clear of any of the three definitions. Illiteracy is associated with an increase in the probability of informality of between 2 and 7 percentage points, with clear evidence that the conditional impact is rising over time. On 
the other hand the possession of a college degree reduces the likelihood of this definition of informality by between 14 and 17 percentage points.

Again there appears to be a regional pattern to informality, once other factors are held. But the marginal effects are in general much smaller than for the other two definitions. There is barely any relationship with urban residence. Geography seems to matter much less if informality is defined according to the characteristics of the employment. Marginal effects for occupation remain statistically significant. However the negative coefficients for creative and technical and administrative occupations in part arise from the exclusion of all the self-employed in these sectors from this definition of informality. Similarly the strong positive association with the domestic, personal and catering services sector arises in part from the inclusion of all domestic workers in this definition of informality.

The likelihood of being in an informal activity is reduced if the worker's spouse is informal, although by only a very small amount. However the sign of this relationship is the opposite of that observed for the other two definitions. Self-employment elsewhere in the family is strongly positively associated with this definition of informality. Marginal effects are three times as large as for definition B and nearer in size to those for definition A. Similarly the negative association between informality and numbers of dependents in the family is similar to that observed for definition A. There is a weak negative association between informal activity and other household income, which is only statistically significant in two of the eight years. This pattern of marginal effects is closest to those for definition B. 


\section{Conclusions}

There is no consensus on how to define the phenomenon of labor market informality in developing economies. In many cases researchers' choice of definition is determined by the availability of data. There has been only cursory discussion in the literature on whether this matters. We conclude in this paper that it does. Using data from Brazilian household surveys we have constructed three alternative definitions of informality, which attempt to reflect the various alternatives used in the literature. Informality is defined according to employment contract status, according to social security protection and, in a manner which is often adopted in previous research, according the nature of the employment and the characteristics of the employer. These three definitions are far from observationally equivalent. Around $64 \%$ of all the economically active in Brazil are informal according to at least one of the three definitions, but only $40 \%$ are informal according to all three definitions. There is a closer correspondence between informality defined by not having a registered employment contract and not contributing to a social security scheme. However substantial numbers of workers are classified as informal if the definition is based on the nature of the employment and the employer, even though they may have registered contracts and/or may contribute towards social security.

Even though overall rates of informality appear constant in Brazil through the 1990s, steady compositional changes are taking place. More women are becoming formal, while men are becoming more informal. Rates of informality are falling among the least skilled (as they decline in importance as a group) while rates of informality are rising quickly among the most skilled (as they increase in importance as a group). There are also occupational changes at work. 
Informality is rising among "higher" occupations and amongst manufacturing and construction groups, whereas it is falling among some service occupations, such as shop-workers and domestic staff. The scale of these changes is dependent on choice of definition. These changes are mirrored in the econometric analysis presented in the paper, as the changing pattern of marginal effects on the likelihood of informality reveals growing heterogeneity within the informal sector.

However the most important conclusion to emerge from econometric analysis is that the conditional impact of particular factors on the likelihood of informality varies considerably from one definition to another. Informality defined according to contract status (labor card) is far less strongly associated with lower educational attainment than it is for the other definitions, in particular the third definition (activity). There are also important differences in the occupational profile of the informal sector between the definitions. For example "higher level" occupations may not have a registered contract, perhaps because they are self-employed or employers, but they do seem to have social protection. Lack of social protection seems to be a rural phenomenon, whereas there is little or no relationship between urban/rural location and the other definitions of informality. The security offered by a registered contract or a large employer seems better to match the family circumstances of those with dependents, but family circumstances do not appear to be strongly associated with social protection. Informal contract status (definition A) and informal activity (definition C) are strongly positively associated with informality elsewhere in the family, especially self-employment. This is not the case for social security status. 
Each of these points merits further research. In particular these differences suggest that the focus of research should shift towards the particular investigation of why workers choose not to have social protection. On the other hand a different avenue of research should focus on the relationship between entrepreneurial activity and informality. Our third definition of informality, based on the characteristics of the employment and the employer, is in empirical terms the most arbitrary. Yet this definition is conceptually well-founded as it corresponds most closely with the notion that informality is related to the degree of entrepreneurial dynamism in a developing economy. There is no a priori reason for believing that such employment activity should of necessity by unregistered and unprotected, and should therefore be regarded as "inferior". The other strong feature of the data investigated in this paper concerns the growing heterogeneity within the informal sector. The reasons why males and those with high levels of educational attainment seem increasingly likely to be found working without contract registration or social protection, or in “informal activity”, merit substantial further analysis. 


\section{Notes:}

${ }^{1}$ For further discussion on modeling and testing for segmentation see Heckman and Sedlacek (1985) and Magnac (1991).

${ }^{2}$ Loayza et al. (2005) argue that a heavier regulatory burden, particularly in product and labor markets, reduces growth and induces informality. They conclude, however, that these effects can be mitigated as the overall institutional framework improves.

${ }^{3}$ Informal workers defined as all non-professional self-employed plus all other employees of firms with under five employees (four in the case of El Salvador).

${ }^{4}$ Gong et al. (2000) report alternative results based on the firm-size definition in an appendix, but these are omitted from the version of this work subsequently published as Gong and van Soest (2002). The two sets of results are described in the later paper as “qualitatively similar”. No results are reported for a definition based on social security coverage.

${ }^{5}$ Prior to the adoption of the 1988 Constitution dismissal notice was fixed at one month. Subsequently it is a minimum of one month rising proportionately with accumulated tenure with the employer. This change is one of the main reasons why Barros and Corseuil (2001) argue that labor market inflexibility may have increased in Brazil.

${ }^{6}$ The structure of the PNAD questionnaire assumes that those who are illiterate must not have received any formal schooling. 


\section{Bibliography}

Barros, R.P. and Corseuil, C.H. (2001), "The impact of regulations on Brazilian labor market performance”, Research Network Working Paper No. R-427, Inter-American Development Bank.

Camargo, J.M. (2002), “Fake contracts: Justice and labor contracts in Brazil”, in World Bank (2002), Brazil: The Jobs Report, Washington, D.C., Report No. 24408-BR.

Carneiro, F.G. (1997), “The changing informal labor market in Brazil: cyclicality versus excessive intervention”, Labor, 11(1): 3-22.

Cohen, B. and House, W.J. (1996), "Labor market choices, earnings and informal networks in Khartoum, Sudan”, Economic Development and Cultural Change, 44(3): 589-618.

Cunningham, W.V. and Maloney, W.F. (2001), “Heterogeneity among Mexico’s microenterprises: an application of factor and cluster analysis”, Economic Development and Cultural Change, 50(1): 131-156.

Fields, G.S. (1975), "Rural-urban migration, urban unemployment and underemployment, and job search activity in LDC’s”, Journal of Development Economics, 2: 165-187.

Funkhouser, E. (1996), "The urban informal sector in Central America: Household survey evidence", World Development, 24(11):1737-51.

Galli, R. and Kucera, D. (2004), "Labor standards and informal employment in Latin America”, World Development, 32(5): 809-828.

Gerxhani, K. (2004), “The informal sector in developed and less developed countries: a literature survey”, Public Choice, 120(3-4): 267-300

Goldberg, P.K. and Pavcnik, N. (2003), “The response of the informal sector to trade liberalization”, Journal of Development Economics, 72(2): 463-496.

Gong, X., van Soest, A. and Villagomez, E. (2000), "Mobility in the urban labor market: a panel data analysis for Mexico”, CentER Discussion Paper, No. 46, Tilburg University.

Gong, X. and van Soest, A. (2002), "Wage differentials and mobility in the urban labor market: a panel data analysis for Mexico”, Labor Economics, 9: 513-529

Hart, K. (1972), Employment, Income and Inequality: A Strategy for Increasing Productive Employment in Kenya, Geneva: ILO.

Heckman, J. and Sedlacek, G. (1985), "Heterogeneity, aggregation and market wage functions: an empirical model of self-selection in the labor market”, Journal of Political Economy, 93: 1077-1125. 
Livingstone, I. (1991), “A reassessment of Kenya’s rural and urban informal sector”, World Development, 19(6): 651-670.

Loayza, N., A.M. Oviedo, and L. Servén (2005), “The impact of regulation on growth and informality: cross-country evidence”, Policy Research Working Paper No. 3623, The World Bank, Washington, D.C.

Magnac, Th. (1991), “Segmented or competitive labor markets”, Econometrica, 59(1): 165-187.

Maloney, W.F. (1999), "Does informality imply segmentation in urban labor markets? Evidence from sectoral transitions in Mexico”, World Bank Economic Review, 13(2): 275-302.

Maloney, W.F. (2004), “Informality revisited”, World Development, 32(7): 1159-1178.

Marcoullier, D., Ruiz de Casilla, V. and Woodruff, C. (1997), "Formal measures of the informalsector wage gap in Mexico, El Salvador, and Peru", Economic Development and Cultural Change, 45(2): 367-92.

Mazumdar, D. (1976), “The urban informal sector”, World Development, 4(8): 655-679.

Merrick, T.W. (1976), "Employment and earnings in the informal sector in Brazil: the case of Belo Horizonte”, Journal of Developing Areas, 10(3): 337-353.

Pisani, M.J. and Pagan, J.A. (2004), "Self-employment in the era of the New Economic Model in Latin America: a case study from Nicaragua”, Entrepreneurship and Regional Development, 16: 335-350.

Portes, A., Blitzner, S. and Curtis, J. (1986), “The urban informal sector in Uruguay: its internal structure, characteristics, and effects”, World Development, 14(6): 727-741.

Pradhan, M. and van Soest, A. (1995), "Formal and informal sector employment in urban areas of Bolivia”, Labor Economics, 2: 275-297.

Pradhan, M. and van Soest, A. (1997), "Household labor supply in urban areas of Bolivia”, Review of Economics and Statistics, 79(2): 300-310.

Saavedra, J. and Chong, A. (1999), "Structural reform, institutions and earnings: Evidence from the formal and informal sectors in urban Peru", Journal of Development Studies, 35(4):95-116.

World Bank (2002), Brazil: The Jobs Report, Washington, D.C., Report No. 24408-BR. 
Table 1: Employment Status - 18-65 year olds

\begin{tabular}{|l|c|c|c|c|c|c|c|c|}
\hline $\begin{array}{l}\text { Employment status - main } \\
\text { occupation \% }\end{array}$ & 1992 & 1993 & 1995 & 1996 & 1997 & 1998 & 1999 & 2001 \\
\hline Employees & 52.6 & 52.8 & 51.4 & 53.2 & 52.2 & 52.7 & 51.7 & 54.1 \\
\hline Self-employed sole traders & 23.2 & 23.2 & 24.1 & 23.6 & 23.9 & 24.1 & 24.1 & 22.9 \\
\hline Employers & 4.1 & 3.9 & 4.3 & 4.0 & 4.4 & 4.4 & 4.3 & 4.4 \\
\hline Domestic workers & 6.2 & 6.4 & 7.1 & 7.1 & 7.4 & 7.1 & 7.5 & 7.8 \\
\hline Non-remunerated workers & 6.5 & 6.6 & 6.3 & 5.9 & 5.8 & 5.6 & 6.1 & 5.0 \\
\hline Subsistence agricultural & 4.4 & 4.3 & 4.1 & 3.7 & 3.8 & 3.6 & 3.7 & 3.2 \\
\hline Temporary workers & 3.1 & 2.9 & 2.7 & 2.5 & 2.6 & 2.5 & 2.5 & 2.6 \\
\hline Total & 100.0 & 100.0 & 100.0 & 100.0 & 100.0 & 100.0 & 100.0 & 100.0 \\
\hline
\end{tabular}

Source: authors' computations from PNAD, population weights 
Table 2: Labor card and social security institute status (in any employment) and informal activity by main employment status

\begin{tabular}{|c|c|c|c|c|c|c|c|c|}
\hline$\%$ & 1992 & 1993 & 1995 & 1996 & 1997 & 1998 & 1999 & 2001 \\
\hline $\begin{array}{l}\text { All economically active } \\
\text { A. No signed labor card } \\
\text { B. No SS Institute member } \\
\text { C. Informal activity }\end{array}$ & $\begin{array}{l}56.7 \\
50.7 \\
49.1 \\
\end{array}$ & $\begin{array}{l}56.0 \\
51.4 \\
48.9 \\
\end{array}$ & $\begin{array}{l}57.5 \\
51.8 \\
50.7 \\
\end{array}$ & $\begin{array}{l}56.7 \\
51.7 \\
50.0 \\
\end{array}$ & $\begin{array}{l}57.3 \\
51.7 \\
50.6 \\
\end{array}$ & $\begin{array}{l}56.4 \\
51.8 \\
50.0 \\
\end{array}$ & $\begin{array}{l}57.8 \\
52.1 \\
49.0 \\
\end{array}$ & $\begin{array}{l}56.0 \\
50.4 \\
49.3 \\
\end{array}$ \\
\hline $\begin{array}{l}\text { Employees } \\
\text { A. No signed labor card } \\
\text { B. No SS Institute member } \\
\text { C. Informal activity } \\
\end{array}$ & $\begin{array}{l}21.1 \\
24.3 \\
12.9 \\
\end{array}$ & $\begin{array}{l}21.2 \\
25.6 \\
12.8 \\
\end{array}$ & $\begin{array}{l}21.8 \\
25.1 \\
14.5 \\
\end{array}$ & $\begin{array}{l}23.2 \\
27.8 \\
15.6 \\
\end{array}$ & $\begin{array}{l}22.9 \\
26.3 \\
15.5 \\
\end{array}$ & $\begin{array}{l}22.8 \\
25.2 \\
15.5 \\
\end{array}$ & $\begin{array}{l}23.8 \\
25.7 \\
15.6 \\
\end{array}$ & $\begin{array}{l}24.0 \\
25.2 \\
16.6 \\
\end{array}$ \\
\hline $\begin{array}{l}\text { Self-employed sole traders } \\
\text { A. No signed labor card } \\
\text { B. No SS Institute member } \\
\text { C. Informal activity }\end{array}$ & $\begin{array}{l}99.2 \\
79.0 \\
95.5\end{array}$ & $\begin{array}{l}97.2 \\
79.1 \\
95.2 \\
\end{array}$ & $\begin{array}{l}99.1 \\
80.9 \\
94.7 \\
\end{array}$ & $\begin{array}{l}99.2 \\
79.7 \\
94.4 \\
\end{array}$ & $\begin{array}{l}99.2 \\
81.1 \\
94.3 \\
\end{array}$ & $\begin{array}{l}97.7 \\
83.0 \\
94.0 \\
\end{array}$ & $\begin{array}{l}98.7 \\
87.1 \\
93.8\end{array}$ & $\begin{array}{l}99.3 \\
84.3 \\
93.0\end{array}$ \\
\hline $\begin{array}{l}\text { Employers } \\
\text { A. No signed labor card } \\
\text { B. No SS Institute member } \\
\text { C. Informal activity }\end{array}$ & $\begin{array}{c}98.4 \\
32.6 \\
0.0 \\
\end{array}$ & $\begin{array}{c}97.9 \\
33.0 \\
0.0 \\
\end{array}$ & $\begin{array}{c}97.5 \\
32.3 \\
7.7 \\
\end{array}$ & $\begin{array}{c}97.1 \\
32.8 \\
7.6 \\
\end{array}$ & $\begin{array}{l}97.6 \\
35.4 \\
10.7 \\
\end{array}$ & $\begin{array}{c}97.6 \\
37.3 \\
9.3 \\
\end{array}$ & $\begin{array}{l}97.4 \\
38.2 \\
11.4 \\
\end{array}$ & $\begin{array}{l}97.8 \\
40.0 \\
11.4 \\
\end{array}$ \\
\hline $\begin{array}{l}\text { Domestic workers } \\
\text { A. No signed labor card } \\
\text { B. No SS Institute member }\end{array}$ & $\begin{array}{l}78.8 \\
76.6\end{array}$ & $\begin{array}{l}79.2 \\
77.9\end{array}$ & $\begin{array}{l}77.5 \\
76.0\end{array}$ & $\begin{array}{l}74.7 \\
73.8\end{array}$ & $\begin{array}{l}74.4 \\
73.0\end{array}$ & $\begin{array}{l}73.0 \\
70.7\end{array}$ & $\begin{array}{l}72.6 \\
70.5\end{array}$ & $\begin{array}{l}71.5 \\
69.1\end{array}$ \\
\hline $\begin{array}{l}\text { Non-remunerated workers } \\
\text { A. Signed labor card } \\
\text { B. SS Institute member } \\
\end{array}$ & $\begin{array}{l}99.9 \\
97.7 \\
\end{array}$ & $\begin{array}{l}99.2 \\
97.1 \\
\end{array}$ & $\begin{array}{l}99.8 \\
97.8 \\
\end{array}$ & $\begin{array}{l}99.8 \\
97.1 \\
\end{array}$ & $\begin{array}{l}99.9 \\
97.0 \\
\end{array}$ & $\begin{array}{l}99.3 \\
97.3 \\
\end{array}$ & $\begin{array}{l}99.5 \\
97.4 \\
\end{array}$ & $\begin{array}{l}99.7 \\
96.9 \\
\end{array}$ \\
\hline $\begin{array}{l}\text { Subsistence agricultural } \\
\text { A. No signed labor card } \\
\text { B. No SS Institute member }\end{array}$ & $\begin{array}{c}100.0 \\
99.3 \\
\end{array}$ & $\begin{array}{c}100.0 \\
99.4 \\
\end{array}$ & $\begin{array}{c}100.0 \\
99.4 \\
\end{array}$ & $\begin{array}{c}100.0 \\
99.0 \\
\end{array}$ & $\begin{array}{c}100.0 \\
99.2 \\
\end{array}$ & $\begin{array}{c}100.0 \\
99.5 \\
\end{array}$ & $\begin{array}{c}100.0 \\
99.5 \\
\end{array}$ & $\begin{array}{r}100.0 \\
99.5 \\
\end{array}$ \\
\hline $\begin{array}{l}\text { Temporary workers } \\
\text { A. No signed labor card } \\
\text { B. No SS Institute member }\end{array}$ & $\begin{array}{l}90.8 \\
91.0\end{array}$ & $\begin{array}{l}89.6 \\
92.0\end{array}$ & $\begin{array}{l}89.7 \\
89.5\end{array}$ & $\begin{array}{l}86.2 \\
86.8\end{array}$ & $\begin{array}{l}89.2 \\
89.2\end{array}$ & $\begin{array}{l}89.8 \\
90.8\end{array}$ & $\begin{array}{l}88.2 \\
88.4\end{array}$ & $\begin{array}{l}88.7 \\
88.5\end{array}$ \\
\hline
\end{tabular}

Source: authors' computations from PNAD, population weights 
Table 3: Correlations of informality measures

\begin{tabular}{|l|c|c|c|}
\hline & $\begin{array}{c}\text { A: No signed } \\
\text { labor card }\end{array}$ & $\begin{array}{c}\text { B: No SS } \\
\text { Institute } \\
\text { Membership }\end{array}$ & $\begin{array}{c}\text { C: Informal } \\
\text { activity }\end{array}$ \\
\hline 1992: & & & \\
\hline A: No signed labor card & 1 & & \\
\hline B: No SS Institute membership & 0.79 & 1 & \\
\hline C: Informal activity & 0.68 & 0.60 & 1 \\
\hline 2001: & 1 & & \\
\hline A: No signed labor card & 0.84 & 1 & \\
\hline B: No SS Institute membership & 0.67 & 0.58 & 1 \\
\hline C: Informal activity & & & \\
\hline
\end{tabular}

Source: authors' computations from PNAD, population weights 
Table 4: Descriptive analysis by informality definition - gender

\begin{tabular}{|l|l|l|l|l|l|l|l|l|}
\hline$\%$ & 1992 & 1993 & 1995 & 1996 & 1997 & 1998 & 1999 & 2001 \\
\hline Male & & & & & & & & \\
A: no signed labor card & 55.5 & 54.5 & 56.6 & 56.7 & 57.3 & 56.6 & 58.1 & 56.7 \\
B: no SS membership & 47.1 & 47.9 & 48.7 & 49.6 & 49.8 & 50.0 & 50.7 & 49.4 \\
C: informal activity & 43.4 & 43.3 & 45.3 & 45.7 & 46.0 & 49.1 & 49.7 & 48.2 \\
\hline Female & & & & & & & & \\
A: no signed labor card & 58.5 & 58.1 & 58.9 & 56.7 & 57.3 & 56.1 & 57.3 & 55.2 \\
B: no SS membership & 56.1 & 56.6 & 56.3 & 54.9 & 54.6 & 53.0 & 54.1 & 51.6 \\
C: informal activity & 57.9 & 57.5 & 58.6 & 56.7 & 57.6 & 57.5 & 58.6 & 56.8 \\
\hline t-test for difference between & & & & & & & & \\
men and women & & & & & & & \\
A: no signed labor card & $10.1^{* *}$ & $11.8^{* *}$ & $7.2^{* *}$ & -1.0 & -0.4 & -1.4 & $-3.5^{* *}$ & $-6.3^{* *}$ \\
B: no SS membership & $28.8^{* *}$ & $27.6^{* *}$ & $24.4^{* *}$ & $15.4^{* *}$ & $13.5^{* *}$ & $9.2^{* *}$ & $9.9^{* *}$ & $6.0^{* *}$ \\
C: informal activity & $50.2^{* *}$ & $49.6^{* *}$ & $47.2^{* *}$ & $39.0^{* *}$ & $42.1^{* *}$ & $36.3^{* *}$ & $38.7^{* *}$ & $37.6^{* *}$ \\
\hline
\end{tabular}

Note: ** denotes $\mathrm{p}<0.01$

Source: authors' computations from PNAD, population weights 
Table 5: Descriptive analysis by informality definition - educational attainment

\begin{tabular}{|c|c|c|c|c|c|c|c|c|}
\hline$\%$ & 1992 & 1993 & 1995 & 1996 & 1997 & 1998 & 1999 & 2001 \\
\hline $\begin{array}{l}\text { All educational levels* } \\
\text { A: no signed labor card } \\
\text { B: no SS membership } \\
\text { C: informal activity }\end{array}$ & $\begin{array}{l}56.5 \\
50.4 \\
48.9 \\
\end{array}$ & $\begin{array}{l}55.8 \\
51.2 \\
48.7 \\
\end{array}$ & $\begin{array}{l}57.4 \\
51.6 \\
50.5\end{array}$ & $\begin{array}{l}56.5 \\
51.5 \\
49.8 \\
\end{array}$ & $\begin{array}{l}57.1 \\
51.6 \\
50.4 \\
\end{array}$ & $\begin{array}{l}56.3 \\
51.0 \\
49.8 \\
\end{array}$ & $\begin{array}{l}57.6 \\
51.9 \\
50.9 \\
\end{array}$ & $\begin{array}{l}56.0 \\
50.3 \\
49.3 \\
\end{array}$ \\
\hline $\begin{array}{l}\text { Illiterate (1992: } 10.6 \% ; 2001: 6.5 \%) \\
\text { A: no signed labor card } \\
\text { B: no SS membership } \\
\text { C: informal activity }\end{array}$ & $\begin{array}{l}82.4 \\
82.0 \\
72.6\end{array}$ & $\begin{array}{l}79.7 \\
83.9 \\
72.7\end{array}$ & $\begin{array}{l}83.0 \\
82.9 \\
74.8\end{array}$ & $\begin{array}{l}83.1 \\
83.0 \\
74.2 \\
\end{array}$ & $\begin{array}{l}83.1 \\
82.9 \\
75.7 \\
\end{array}$ & $\begin{array}{l}79.1 \\
83.3 \\
74.8\end{array}$ & $\begin{array}{l}83.5 \\
85.0 \\
76.8 \\
\end{array}$ & $\begin{array}{l}83.5 \\
82.5 \\
77.5 \\
\end{array}$ \\
\hline $\begin{array}{l}\text { Elementary (1992: } 27.4 \% ; 2001: 15.5 \%) \\
\text { A: no signed labor card } \\
\text { B: no SS membership } \\
\text { C: informal activity }\end{array}$ & $\begin{array}{l}66.8 \\
58.1 \\
60.8\end{array}$ & $\begin{array}{l}65.6 \\
58.4 \\
60.8\end{array}$ & $\begin{array}{l}68.7 \\
60.6 \\
63.8\end{array}$ & $\begin{array}{l}68.2 \\
60.0 \\
64.1\end{array}$ & $\begin{array}{l}70.2 \\
62.0 \\
66.0\end{array}$ & $\begin{array}{l}69.7 \\
62.7 \\
66.3\end{array}$ & $\begin{array}{l}70.7 \\
63.5 \\
67.0\end{array}$ & $\begin{array}{l}71.1 \\
64.0 \\
67.8\end{array}$ \\
\hline $\begin{array}{l}\text { Primary (1992: 34.7\%; 2001: 38.7\%) } \\
\text { A: no signed labor card } \\
\text { B: no SS membership } \\
\text { C: informal activity }\end{array}$ & $\begin{array}{l}59.2 \\
55.2 \\
53.1 \\
\end{array}$ & $\begin{array}{l}59.4 \\
56.7 \\
53.1 \\
\end{array}$ & $\begin{array}{l}60.9 \\
57.5 \\
56.2 \\
\end{array}$ & $\begin{array}{l}60.3 \\
57.5 \\
55.7 \\
\end{array}$ & $\begin{array}{l}61.6 \\
58.2 \\
56.9 \\
\end{array}$ & $\begin{array}{l}61.4 \\
58.2 \\
57.1 \\
\end{array}$ & $\begin{array}{l}63.3 \\
59.8 \\
58.8 \\
\end{array}$ & $\begin{array}{l}63.1 \\
59.4 \\
58.6 \\
\end{array}$ \\
\hline $\begin{array}{l}\text { Secondary (1992: } 17.5 \% ; 2001: 26.2 \%) \\
\text { A: no signed labor card } \\
\text { B: no SS membership } \\
\text { C: informal activity }\end{array}$ & $\begin{array}{l}36.1 \\
29.1 \\
28.4\end{array}$ & $\begin{array}{l}36.9 \\
30.6 \\
29.9\end{array}$ & $\begin{array}{l}38.6 \\
32.2 \\
31.5\end{array}$ & $\begin{array}{l}39.3 \\
34.4 \\
32.6 \\
\end{array}$ & $\begin{array}{l}39.7 \\
33.7 \\
32.8 \\
\end{array}$ & $\begin{array}{l}40.3 \\
33.7 \\
33.5\end{array}$ & $\begin{array}{l}41.6 \\
35.2 \\
35.0\end{array}$ & $\begin{array}{l}41.4 \\
35.5 \\
34.9\end{array}$ \\
\hline $\begin{array}{l}\text { College deg. (1992: 9.1\%; 2001: 12.3\%) } \\
\text { A: no signed labor card } \\
\text { B: no SS membership } \\
\text { C: informal activity }\end{array}$ & $\begin{array}{l}25.8 \\
14.8 \\
10.7 \\
\end{array}$ & $\begin{array}{l}26.7 \\
15.7 \\
10.7\end{array}$ & $\begin{array}{l}30.1 \\
17.0 \\
12.4 \\
\end{array}$ & $\begin{array}{l}30.8 \\
19.6 \\
13.6 \\
\end{array}$ & $\begin{array}{l}31.7 \\
19.4 \\
14.1 \\
\end{array}$ & $\begin{array}{l}33.3 \\
19.5 \\
13.7 \\
\end{array}$ & $\begin{array}{l}32.9 \\
19.2 \\
13.7\end{array}$ & $\begin{array}{l}32.8 \\
20.5 \\
14.3 \\
\end{array}$ \\
\hline $\begin{array}{l}\text { Postgrad deg. (1992: } 0.4 \% ; 2001: 0.8 \%) \\
\text { A: no signed labor card } \\
\text { B: no SS membership } \\
\text { C: informal activity }\end{array}$ & $\begin{array}{l}17.9 \\
9.7 \\
3.7 \\
\end{array}$ & $\begin{array}{l}16.1 \\
9.4 \\
3.5 \\
\end{array}$ & $\begin{array}{l}18.2 \\
13.7 \\
5.3 \\
\end{array}$ & $\begin{array}{l}18.7 \\
13.8 \\
5.6 \\
\end{array}$ & $\begin{array}{l}19.9 \\
12.8 \\
6.3 \\
\end{array}$ & $\begin{array}{l}23.2 \\
14.1 \\
5.9 \\
\end{array}$ & $\begin{array}{l}23.1 \\
11.3 \\
6.6 \\
\end{array}$ & $\begin{array}{l}27.3 \\
22.7 \\
18.9 \\
\end{array}$ \\
\hline
\end{tabular}


Note: * Observations with missing information on educational attainment comprise $1.44 \%$ and $1.39 \%$ of the total sample in 1992 and 2001 respectively.

Source: authors' computations from PNAD, population weights 
Table 6: Descriptive analysis by informality definition - establishment size (excluding agriculture*)

\begin{tabular}{|c|c|c|c|c|c|c|c|c|}
\hline$\%$ & 1992 & 1993 & 1995 & 1996 & 1997 & 1998 & 1999 & 2001 \\
\hline $\begin{array}{l}\text { One (1992: 22.5\%; } 2001 \text { 22.8\%: ) } \\
\text { A: no signed labor card } \\
\text { B: no SS membership } \\
\text { C: informal activity }\end{array}$ & $\begin{array}{l}99.1 \\
70.2 \\
88.7\end{array}$ & $\begin{array}{l}98.7 \\
71.1 \\
88.7\end{array}$ & $\begin{array}{l}99.0 \\
73.3 \\
88.6 \\
\end{array}$ & $\begin{array}{l}98.9 \\
72.2 \\
88.0\end{array}$ & $\begin{array}{l}99.0 \\
74.0 \\
88.3\end{array}$ & $\begin{array}{l}98.9 \\
76.9 \\
88.0 \\
\end{array}$ & $\begin{array}{l}99.1 \\
77.5 \\
88.1 \\
\end{array}$ & $\begin{array}{l}99.1 \\
79.2 \\
87.2 \\
\end{array}$ \\
\hline $\begin{array}{l}\text { Two (1992: 3.6\%; 2001: 4.3\%) } \\
\text { A: no signed labor card } \\
\text { B: no SS membership } \\
\text { C: informal activity }\end{array}$ & $\begin{array}{l}80.1 \\
60.3 \\
76.6 \\
\end{array}$ & $\begin{array}{l}81.0 \\
60.6 \\
76.8 \\
\end{array}$ & $\begin{array}{l}81.3 \\
61.5 \\
79.1 \\
\end{array}$ & $\begin{array}{l}75.2 \\
61.5 \\
83.3 \\
\end{array}$ & $\begin{array}{l}78.1 \\
62.1 \\
81.3 \\
\end{array}$ & $\begin{array}{l}79.1 \\
63.0 \\
80.5 \\
\end{array}$ & $\begin{array}{l}78.3 \\
62.6 \\
80.7 \\
\end{array}$ & $\begin{array}{l}78.4 \\
64.5 \\
82.3 \\
\end{array}$ \\
\hline $\begin{array}{l}3 \text { to } 5 \text { (1992: 7.4\%; 2001: 8.7\%) } \\
\text { A: no signed labor card } \\
\text { B: no SS membership } \\
\text { C: informal activity }\end{array}$ & $\begin{array}{l}64.2 \\
50.6 \\
84.9\end{array}$ & $\begin{array}{l}65.5 \\
53.0 \\
85.3\end{array}$ & $\begin{array}{l}63.6 \\
50.6 \\
86.2\end{array}$ & $\begin{array}{l}62.1 \\
52.1 \\
88.2\end{array}$ & $\begin{array}{l}63.8 \\
51.9 \\
86.4\end{array}$ & $\begin{array}{l}62.9 \\
50.0 \\
86.4\end{array}$ & $\begin{array}{l}63.1 \\
51.2 \\
87.3 \\
\end{array}$ & $\begin{array}{l}62.4 \\
51.1 \\
87.7 \\
\end{array}$ \\
\hline $\begin{array}{l}6 \text { to } 10(1992: 5.9 \% ; 2001: 7.1) \\
\text { A: no signed labor card } \\
\text { B: no SS membership } \\
\text { C: informal activity }\end{array}$ & $\begin{array}{l}42.5 \\
34.2 \\
0.0 \\
\end{array}$ & $\begin{array}{l}44.9 \\
36.3 \\
0.0 \\
\end{array}$ & $\begin{array}{l}41.6 \\
33.0 \\
0.0 \\
\end{array}$ & $\begin{array}{l}42.0 \\
36.0 \\
0.0\end{array}$ & $\begin{array}{l}40.4 \\
33.1 \\
0.0 \\
\end{array}$ & $\begin{array}{l}42.0 \\
32.7 \\
0.0 \\
\end{array}$ & $\begin{array}{l}43.0 \\
34.1 \\
0.0 \\
\end{array}$ & $\begin{array}{l}42.0 \\
34.0 \\
0.0 \\
\end{array}$ \\
\hline $\begin{array}{l}11 \text { or more (1992: 49.8\%; 2001: } \\
45.2 \% \text { ) } \\
\text { A: no signed labor card } \\
\text { B: no SS membership } \\
\text { C: informal activity }\end{array}$ & $\begin{array}{l}8.1 \\
11.7 \\
0.0\end{array}$ & $\begin{array}{l}8.2 \\
13.4 \\
0.0\end{array}$ & $\begin{array}{l}8.6 \\
12.7 \\
0.0\end{array}$ & $\begin{array}{l}9.8 \\
15.5 \\
0.0\end{array}$ & $\begin{array}{l}10.0 \\
14.1 \\
0.0\end{array}$ & $\begin{array}{l}10.3 \\
13.5 \\
0.0\end{array}$ & $\begin{array}{l}11.1 \\
13.7 \\
0.0\end{array}$ & $\begin{array}{l}11.6 \\
13.1 \\
0.0\end{array}$ \\
\hline $\begin{array}{l}\text { Establishment size unknown (1992: } \\
\text { 10.8\%; 2001: } 11.8 \%) \\
\text { A: no signed labor card } \\
\text { B: no SS membership } \\
\text { C: informal activity }\end{array}$ & $\begin{array}{l}83.6 \\
80.3 \\
99.8 \\
\end{array}$ & $\begin{array}{l}83.7 \\
81.5 \\
99.5 \\
\end{array}$ & $\begin{array}{l}82.3 \\
79.9 \\
99.7 \\
\end{array}$ & $\begin{array}{l}79.8 \\
77.7 \\
99.8 \\
\end{array}$ & $\begin{array}{l}79.6 \\
77.2 \\
99.9 \\
\end{array}$ & $\begin{array}{l}78.5 \\
75.6 \\
99.6 \\
\end{array}$ & $\begin{array}{l}78.2 \\
75.3 \\
99.7 \\
\end{array}$ & $\begin{array}{l}76.6 \\
73.6 \\
99.6 \\
\end{array}$ \\
\hline
\end{tabular}

Note: *Agriculture is omitted because the questionnaire schedule for agricultural workers is subdivided into grouped responses for temporary and permanent workers.

Source: authors' computations from PNAD, population weights 
Table 7: Descriptive analysis by informality definition - occupational sector

\begin{tabular}{|c|c|c|c|c|c|c|c|c|}
\hline$\%$ & 1992 & 1993 & 1995 & 1996 & 1997 & 1998 & 1999 & 2001 \\
\hline $\begin{array}{l}\text { Creative and Technical } \\
\text { (1992: 8.1\%; 2001: 9.5\%) } \\
\text { A: no signed labor card } \\
\text { B: no SS membership } \\
\text { C: informal activity }\end{array}$ & $\begin{array}{l}20.2 \\
18.4 \\
4.5 \\
\end{array}$ & $\begin{array}{l}19.7 \\
19.0 \\
3.9 \\
\end{array}$ & $\begin{array}{l}23.3 \\
20.8 \\
4.8\end{array}$ & $\begin{array}{l}23.7 \\
23.1 \\
5.0 \\
\end{array}$ & $\begin{array}{l}24.5 \\
21.0 \\
4.5\end{array}$ & $\begin{array}{l}25.6 \\
20.6 \\
5.0\end{array}$ & $\begin{array}{l}25.6 \\
19.8 \\
4.3 \\
\end{array}$ & $\begin{array}{l}27.2 \\
21.4 \\
5.5 \\
\end{array}$ \\
\hline $\begin{array}{l}\text { Administrative } \\
\text { (1992: 14.0\%; 2001: 13.4\%) } \\
\text { A: no signed labor card } \\
\text { B: no SS membership } \\
\text { C: informal activity }\end{array}$ & $\begin{array}{l}34.5 \\
18.1 \\
7.0\end{array}$ & $\begin{array}{l}35.3 \\
18.8 \\
7.2\end{array}$ & $\begin{array}{l}35.6 \\
18.6 \\
8.1\end{array}$ & $\begin{array}{l}35.3 \\
20.6 \\
9.7\end{array}$ & $\begin{array}{l}35.8 \\
19.9 \\
9.2\end{array}$ & $\begin{array}{l}37.3 \\
20.0 \\
9.4\end{array}$ & $\begin{array}{l}37.3 \\
20.2 \\
9.8\end{array}$ & $\begin{array}{l}37.5 \\
21.1 \\
10.2\end{array}$ \\
\hline $\begin{array}{l}\text { Agricultural } \\
\text { (1992: 23.2\%; 2001: 17.2\%) } \\
\text { A: no signed labor card } \\
\text { B: no SS membership } \\
\text { C: informal activity } \\
\end{array}$ & $\begin{array}{l}91.4 \\
90.2 \\
81.9 \\
\end{array}$ & $\begin{array}{l}88.3 \\
89.8 \\
81.6 \\
\end{array}$ & $\begin{array}{l}90.7 \\
89.6 \\
82.2 \\
\end{array}$ & $\begin{array}{l}90.0 \\
88.3 \\
81.1 \\
\end{array}$ & $\begin{array}{l}90.2 \\
88.7 \\
81.8 \\
\end{array}$ & $\begin{array}{l}88.5 \\
89.1 \\
82.9\end{array}$ & $\begin{array}{l}89.4 \\
88.2 \\
82.7 \\
\end{array}$ & $\begin{array}{l}89.8 \\
88.0 \\
82.5 \\
\end{array}$ \\
\hline $\begin{array}{l}\text { Manufacturing and construction } \\
\text { (1992: 18.9\%; 2001: 19.1\%) } \\
\text { A: no signed labor card } \\
\text { B: no SS membership } \\
\text { C: informal activity }\end{array}$ & $\begin{array}{l}52.6 \\
46.2 \\
47.3 \\
\end{array}$ & $\begin{array}{l}53.3 \\
47.5 \\
47.4 \\
\end{array}$ & $\begin{array}{l}56.4 \\
49.7 \\
51.4\end{array}$ & $\begin{array}{l}56.9 \\
50.8 \\
51.5 \\
\end{array}$ & $\begin{array}{l}57.9 \\
51.5 \\
52.9 \\
\end{array}$ & $\begin{array}{l}58.4 \\
52.2 \\
52.9\end{array}$ & $\begin{array}{l}59.0 \\
52.8 \\
52.6 \\
\end{array}$ & $\begin{array}{l}57.5 \\
52.3 \\
51.3 \\
\end{array}$ \\
\hline $\begin{array}{l}\text { Retail and Distribution } \\
\text { (1992: 11.0\%; 2001: 12.6\%) } \\
\text { A: no signed labor card } \\
\text { B: no SS membership } \\
\text { C: informal activity }\end{array}$ & $\begin{array}{l}72.8 \\
54.4 \\
74.0 \\
\end{array}$ & $\begin{array}{l}74.0 \\
56.7 \\
74.5 \\
\end{array}$ & $\begin{array}{l}74.4 \\
58.3 \\
75.5 \\
\end{array}$ & $\begin{array}{l}72.6 \\
57.5 \\
73.2 \\
\end{array}$ & $\begin{array}{l}72.4 \\
57.9 \\
73.2 \\
\end{array}$ & $\begin{array}{l}71.3 \\
57.7 \\
72.5 \\
\end{array}$ & $\begin{array}{l}72.1 \\
59.3 \\
72.2 \\
\end{array}$ & $\begin{array}{l}69.1 \\
58.3 \\
69.6 \\
\end{array}$ \\
\hline $\begin{array}{l}\text { Transport and Communications } \\
\text { (1992: 4.2\%; 2001: 4.5\%) } \\
\text { A: no signed labor card } \\
\text { B: no SS membership } \\
\text { C: informal activity }\end{array}$ & $\begin{array}{l}33.0 \\
24.1 \\
29.2\end{array}$ & $\begin{array}{l}32.1 \\
23.5 \\
29.1\end{array}$ & $\begin{array}{l}35.9 \\
27.7 \\
33.1\end{array}$ & $\begin{array}{l}38.5 \\
31.6 \\
35.2\end{array}$ & $\begin{array}{l}40.5 \\
32.9 \\
35.4\end{array}$ & $\begin{array}{l}41.5 \\
32.8 \\
37.1\end{array}$ & $\begin{array}{l}44.4 \\
34.7 \\
39.6\end{array}$ & $\begin{array}{l}42.8 \\
34.2 \\
38.0\end{array}$ \\
\hline
\end{tabular}




\begin{tabular}{|c|c|c|c|c|c|c|c|c|}
\hline $\begin{array}{l}\text { Domestic, Personal and Catering } \\
\text { Services (1992: 9.7\%; 2001: 1.9\%) } \\
\text { A: no signed labor card } \\
\text { B: no SS membership } \\
\text { C: informal activity }\end{array}$ & $\begin{array}{l}71.0 \\
68.3 \\
83.8\end{array}$ & $\begin{array}{l}71.8 \\
69.8 \\
84.2\end{array}$ & $\begin{array}{l}71.1 \\
68.5 \\
84.9\end{array}$ & $\begin{array}{l}68.7 \\
66.9 \\
84.8\end{array}$ & $\begin{array}{l}68.7 \\
66.8 \\
85.2\end{array}$ & $\begin{array}{l}67.3 \\
64.1 \\
83.5\end{array}$ & $\begin{array}{l}67.9 \\
65.4 \\
85.7\end{array}$ & $\begin{array}{l}66.4 \\
63.5 \\
84.4\end{array}$ \\
\hline $\begin{array}{l}\text { Other } \\
\text { (1992: 10.9\%; 2001: 12.0\%) } \\
\text { A: no signed labor card } \\
\text { B: no SS membership } \\
\text { C: informal activity }\end{array}$ & $\begin{array}{l}24.5 \\
30.9 \\
21.3\end{array}$ & $\begin{array}{l}23.5 \\
32.6 \\
20.4\end{array}$ & $\begin{array}{l}24.3 \\
32.0 \\
21.5\end{array}$ & $\begin{array}{l}25.8 \\
33.5 \\
22.3\end{array}$ & $\begin{array}{l}26.7 \\
33.1 \\
23.3\end{array}$ & $\begin{array}{l}27.1 \\
35.1 \\
23.4\end{array}$ & $\begin{array}{l}29.9 \\
36.6 \\
25.9\end{array}$ & $\begin{array}{l}30.2 \\
34.3 \\
26.3\end{array}$ \\
\hline
\end{tabular}

Source: authors' computations from PNAD, population weights 
Table 8: Probit Estimates - No Signed Labor Card

\begin{tabular}{|c|c|c|c|c|c|c|c|c|}
\hline & 1992 & 1993 & 1995 & 1996 & 1997 & 1998 & 1999 & 2001 \\
\hline Age & $-0.007 * *$ & $-0.009 * *$ & $-0.005 * *$ & $-0.008 * *$ & $-0.007 * *$ & $-0.011 * *$ & $-0.011^{* *}$ & $-0.012 * *$ \\
\hline Age squared & $0.00013^{* *}$ & $0.00016^{* *}$ & $0.00011^{* *}$ & $0.00015^{* *}$ & $0.00014 * *$ & $0.00019 * *$ & $0.00018^{* *}$ & $0.00021 * *$ \\
\hline Female & $-0.053 * *$ & $-0.050 * *$ & $-0.059 * *$ & $-0.060 * *$ & $-0.073 * *$ & $-0.063 * *$ & $-0.070 * *$ & $-0.061 * *$ \\
\hline $\begin{array}{l}\text { Ethnicity (reference: White) } \\
\text { Indigenous } \\
\text { Black } \\
\text { Asian } \\
\text { Mixed }\end{array}$ & $\begin{array}{c}0.078 \\
-0.024^{* *} \\
0.081^{*} \\
0.0001\end{array}$ & $\begin{array}{c}-0.020 \\
-0.026^{* *} \\
0.071^{*} \\
0.010^{*}\end{array}$ & $\begin{array}{c}0.169 * \\
-0.049 * * \\
0.142 * * \\
0.003 \\
\end{array}$ & $\begin{array}{c}0.140 * * \\
-0.038 * * \\
0.132 * * \\
-0.003\end{array}$ & $\begin{array}{c}0.071 \\
-0.035^{* *} \\
0.131^{* *} \\
0.002 \\
\end{array}$ & $\begin{array}{c}0.073 \\
-0.018^{*} \\
0.131^{* *} \\
-0.004 \\
\end{array}$ & $\begin{array}{c}0.150^{* *} \\
-0.022^{* *} \\
0.115^{* *} \\
0.001 \\
\end{array}$ & $\begin{array}{c}-0.033 \\
-0.030^{* *} \\
0.067 * \\
-0.002\end{array}$ \\
\hline Illiterate & $0.059 * *$ & $0.071 * *$ & $0.072 * *$ & $0.074 * *$ & $0.068 * *$ & $0.053 * *$ & $0.070 * *$ & $0.088 * *$ \\
\hline $\begin{array}{l}\text { Schooling (reference: Elementary) } \\
\text { Primary } \\
\text { Secondary } \\
\text { College degree } \\
\text { Postgraduate degree } \\
\end{array}$ & $\begin{array}{c}0.002 \\
-0.073^{* *} \\
0.0006 \\
-0.073 \\
\end{array}$ & $\begin{array}{c}0.018 * * \\
-0.069 * * \\
0.008 \\
-0.115^{* *} \\
\end{array}$ & $\begin{array}{c}0.019 * * \\
-0.066^{* *} \\
0.011 \\
-0.102^{* *}\end{array}$ & $\begin{array}{c}0.0005 \\
-0.075^{* *} \\
-0.002 \\
-0.122 * * \\
\end{array}$ & $\begin{array}{c}0.015^{*} \\
-0.070^{* *} \\
-0.009 \\
-0.140^{* *}\end{array}$ & $\begin{array}{c}0.015^{*} \\
-0.060^{* *} \\
0.013 \\
-0.033 \\
\end{array}$ & $\begin{array}{c}0.018 * * \\
-0.069 * * \\
0.004 \\
-0.048 \\
\end{array}$ & $\begin{array}{c}0.025^{* *} \\
-0.063^{* *} \\
-0.007 \\
-0.128^{* *}\end{array}$ \\
\hline $\begin{array}{l}\text { Region (reference: South East) } \\
\text { North } \\
\text { Centre East } \\
\text { South } \\
\text { North East } \\
\end{array}$ & $\begin{array}{l}0.155^{* *} \\
0.094 * * \\
0.019 * * \\
0.128 * *\end{array}$ & $\begin{array}{c}0.126 * * \\
0.076 * * \\
0.008 \\
0.089 * *\end{array}$ & $\begin{array}{l}0.126 * * \\
0.076 * * \\
0.033 * * \\
0.137 * *\end{array}$ & $\begin{array}{l}0.120 * * \\
0.069 * * \\
0.019 * * \\
0.114 * *\end{array}$ & $\begin{array}{c}0.139 * * \\
0.054 * * \\
0.002 \\
0.110 * *\end{array}$ & $\begin{array}{l}0.139 * * \\
0.056 * * \\
0.023 * * \\
0.111 * *\end{array}$ & $\begin{array}{l}0.136 * * \\
0.053 * * \\
0.014 * * \\
0.125 * *\end{array}$ & $\begin{array}{l}0.103 * * \\
0.034 * * \\
0.017 * * \\
0.118^{* *}\end{array}$ \\
\hline Urban resident & $-0.049 * *$ & $-0.015 *$ & $-0.041^{* *}$ & $-0.022 * *$ & $-0.036 * *$ & 0.004 & 0.0003 & $-0.030 * *$ \\
\hline Union member & $-0.236 * *$ & $-0.232 * *$ & $-0.242 * *$ & $-0.233^{*} *$ & $-0.250 * *$ & $-0.245 * *$ & $-0.249 * *$ & $-0.231 * *$ \\
\hline Establishment $>11$ employees & $-0.675 * *$ & $-0.671 * *$ & $-0.661 * *$ & $-0.627 * *$ & $-0.633 * *$ & $-0.630 * *$ & $-0.627 * *$ & $-0.616 * *$ \\
\hline $\begin{array}{l}\text { Occupation (reference: Other) } \\
\text { Creative and technical } \\
\text { Administrative } \\
\text { Agricultural } \\
\text { Production and construction } \\
\text { Retail and distribution } \\
\text { Transport and comms } \\
\text { Domestic, personal and } \\
\text { catering services }\end{array}$ & $\begin{array}{l}0.030 * * \\
0.091 * * \\
0.168 * * \\
0.197^{* *} \\
0.193 * * \\
0.093 * * \\
0.150^{* *}\end{array}$ & $\begin{array}{l}0.038 * * \\
0.096 * * \\
0.142 * * \\
0.212 * * \\
0.203 * * \\
0.089 * * \\
0.157 * *\end{array}$ & $\begin{array}{l}0.045 * * \\
0.085 * * \\
0.173 * * \\
0.224 * * \\
0.214 * * \\
0.102 * * \\
0.181 * *\end{array}$ & $\begin{array}{l}0.033 * * \\
0.065 * * \\
0.186 * * \\
0.207 * * \\
0.202 * * \\
0.103 * * \\
0.156 * *\end{array}$ & $\begin{array}{l}0.043 * * \\
0.058 * * \\
0.168 * * \\
0.194 * * \\
0.191 * * \\
0.118 * * \\
0.142 * *\end{array}$ & $\begin{array}{l}0.033 * * \\
0.065 * * \\
0.152 * * \\
0.198 * * \\
0.173 * * \\
0.117 * * \\
0.125 * *\end{array}$ & $\begin{array}{l}0.041^{* *} \\
0.056 * * \\
0.142^{* *} \\
0.200^{* *} \\
0.176^{* *} \\
0.129^{* *} \\
0.122^{* *}\end{array}$ & $\begin{array}{l}0.027 * * \\
0.048 * * \\
0.150 * * \\
0.181 * * \\
0.151 * * \\
0.108 * * \\
0.100 * *\end{array}$ \\
\hline
\end{tabular}




\begin{tabular}{|c|c|c|c|c|c|c|c|c|}
\hline Spouse working with no labor card & $0.037 * *$ & $0.022 * *$ & $0.025 * *$ & $0.025 * *$ & $0.021 * *$ & $0.022 * *$ & $0.014^{* *}$ & $0.031^{* *}$ \\
\hline Family total with labor cards & $-0.026 * *$ & $-0.025^{* *}$ & $-0.027 * *$ & $-0.028 * *$ & $-0.025^{* *}$ & $-0.032 * *$ & $-0.027 * *$ & $-0.025 * *$ \\
\hline Family total self-employed & $0.139 * *$ & $0.139 * *$ & $0.147 * *$ & $0.159 * *$ & $0.155^{* *}$ & $0.148 * *$ & $0.152 * *$ & $0.140^{* *}$ \\
\hline Family total number of children & $-0.010 * *$ & $-0.010 * *$ & $-0.014^{* *}$ & $-0.011 * *$ & $-0.011 * *$ & $-0.010 * *$ & $-0.011 * *$ & $-0.011 * *$ \\
\hline Family total number over 65 & $-0.025 * *$ & $-0.022 * *$ & $-0.018 * *$ & $-0.026 * *$ & $-0.020^{* *}$ & $-0.022 * *$ & $-0.020 * *$ & $-0.018 * *$ \\
\hline Other family earnings per head & $-.39 \times 10^{-8} * *$ & $.15 \times 10^{-7}$ & $.26 \times 10^{-4} * *$ & $.26 \times 10^{-4} * *$ & $.38 \times 10^{-4} * *$ & $.45 \times 10^{-4} * *$ & $.35 \times 10^{-4} * *$ & $.32 \times 10^{-4} * *$ \\
\hline Sample size & 103,700 & 105,031 & 112,127 & 108,924 & 116,120 & 115,011 & 118,767 & 132,534 \\
\hline Log likelihood & -35275.7 & -36438.4 & -39000.0 & -40349.0 & -42835.6 & -43755.5 & -45398.1 & -52032.1 \\
\hline
\end{tabular}

Note: reported coefficients are marginal effects (which in the case of binary variables are for a discrete change in the variable)

* denotes $\mathrm{p}<0.05$; ** denotes $\mathrm{p}<0.01$; 
Table 9: Probit Estimates - No Social Security Membership

\begin{tabular}{|c|c|c|c|c|c|c|c|c|}
\hline & 1992 & 1993 & 1995 & 1996 & 1997 & 1998 & 1999 & 2001 \\
\hline Age & $-0.028 * *$ & $-0.028 * *$ & $-0.025 * *$ & $-0.025 * *$ & $-0.025 * *$ & $-0.026 * *$ & $-0.025 * *$ & $-0.026 * *$ \\
\hline Age squared & $0.00031^{* *}$ & $0.00031^{* *}$ & $0.00029 * *$ & $0.00028 * *$ & $0.00028 * *$ & $0.00030 *$ & $0.00030 *$ & $0.00030 *$ \\
\hline Female & $0.062 * *$ & $0.060 * *$ & $0.050 * *$ & $0.044^{* *}$ & $0.021 * *$ & $0.026^{* *}$ & $0.024 * *$ & $0.026 * *$ \\
\hline $\begin{array}{l}\text { Ethnicity (reference: White) } \\
\text { Indigenous } \\
\text { Black } \\
\text { Asian } \\
\text { Mixed }\end{array}$ & $\begin{array}{c}0.068 \\
0.012 \\
-0.053 \\
0.033^{* *}\end{array}$ & $\begin{array}{c}0.158^{*} \\
0.006 \\
-0.060^{*} \\
0.041^{* *}\end{array}$ & $\begin{array}{c}0.100 \\
-0.006 \\
-0.091^{* *} \\
0.035^{* *}\end{array}$ & $\begin{array}{c}0.043 \\
0.011 \\
-0.025 \\
0.024^{* *}\end{array}$ & $\begin{array}{c}0.151 * * \\
-0.001 \\
0.013 \\
0.025 * *\end{array}$ & $\begin{array}{c}0.098 * * \\
-0.001 \\
0.028 \\
0.031 * *\end{array}$ & $\begin{array}{c}0.166^{* *} \\
0.004 \\
-0.019 \\
0.026^{* *}\end{array}$ & $\begin{array}{c}0.008 \\
-0.003 \\
-0.010 \\
0.023^{* *}\end{array}$ \\
\hline Illiterate & $0.094 * *$ & $0.135^{* *}$ & $0.098 * *$ & $0.097^{* *}$ & $0.090 * *$ & $0.115^{* *}$ & $0.116^{* *}$ & $0.100 * *$ \\
\hline $\begin{array}{l}\text { Schooling (reference: Elementary) } \\
\text { Primary } \\
\text { Secondary } \\
\text { College degree } \\
\text { Postgraduate degree } \\
\end{array}$ & $\begin{array}{c}-0.049 * * \\
-0.093 * * \\
-0.085 * * \\
-0.025\end{array}$ & $\begin{array}{l}-0.040 * * \\
-0.099 * * \\
-0.090 * * \\
-0.097 * *\end{array}$ & $\begin{array}{c}-0.036^{* *} \\
-0.096 * * \\
-0.110^{* *} \\
-0.068^{*}\end{array}$ & $\begin{array}{l}-0.039 * * \\
-0.097 * * \\
-0.100 * * \\
-0.129 * *\end{array}$ & $\begin{array}{l}-0.035^{* *} \\
-0.104 * * \\
-0.108 * * \\
-0.164 * *\end{array}$ & $\begin{array}{l}-0.040^{* *} \\
-0.107^{* *} \\
-0.101^{* *} \\
-0.096^{* *}\end{array}$ & $\begin{array}{l}-0.033^{* *} \\
-0.118^{* *} \\
-0.124^{* *} \\
-0.166^{* *}\end{array}$ & $\begin{array}{l}-0.026 * * \\
-0.114 * * \\
-0.116 * * \\
-0.153^{* *}\end{array}$ \\
\hline $\begin{array}{l}\text { Region (reference: South East) } \\
\text { North } \\
\text { Centre East } \\
\text { South } \\
\text { North East } \\
\end{array}$ & $\begin{array}{l}0.272 * * \\
0.159 * * \\
0.026 * * \\
0.205 * *\end{array}$ & $\begin{array}{c}0.253 * * \\
0.162 * * \\
0.009 \\
0.215 * * \\
\end{array}$ & $\begin{array}{l}0.239 * * \\
0.145 * * \\
0.025 * * \\
0.190 * *\end{array}$ & $\begin{array}{c}0.224 * * \\
0.137 * * \\
-0.002 \\
0.179 * * \\
\end{array}$ & $\begin{array}{c}0.240 * * \\
0.123 * * \\
0.003 \\
0.183 * * \\
\end{array}$ & $\begin{array}{c}0.216 * * \\
0.112 * * \\
0.007 \\
0.189 * * \\
\end{array}$ & $\begin{array}{c}0.225^{* *} \\
0.121^{* *} \\
-0.005 \\
0.205^{* *}\end{array}$ & $\begin{array}{c}0.181^{* *} \\
0.088^{* *} \\
0.003 \\
0.177^{* *}\end{array}$ \\
\hline Urban resident & $-0.117 * *$ & $-0.126 * *$ & $-0.112 * *$ & $-0.075 * *$ & $-0.098 * *$ & $-0.094 * *$ & $-0.071 * *$ & $-0.089 * *$ \\
\hline Union member & $-0.241^{* *}$ & $-0.251^{* *}$ & $-0.253 * *$ & $-0.248 * *$ & $-0.261 * *$ & $-0.272^{* *}$ & $-0.267 * *$ & $-0.257 * *$ \\
\hline Establishment > 11 employees & $-0.474 * *$ & $-0.469 * *$ & $-0.462 * *$ & $-0.419 * *$ & $-0.442 * *$ & $-0.465 * *$ & $-0.464 * *$ & $-0.472 * *$ \\
\hline $\begin{array}{l}\text { Occupation (reference: Other) } \\
\text { Creative and technical } \\
\text { Administrative } \\
\text { Agricultural } \\
\text { Production and construction } \\
\text { Retail and distribution } \\
\text { Transport and comms } \\
\text { Domestic, personal and } \\
\text { catering services }\end{array}$ & $\begin{array}{c}-0.089 * * \\
-0.217^{* *} \\
0.146 * * \\
0.029 * * \\
-0.062 * * \\
-0.095^{* *} \\
0.030 * *\end{array}$ & $\begin{array}{c}-0.077^{* *} \\
-0.206 * * \\
0.137^{* *} \\
0.034^{* *} \\
-0.053^{* *} \\
-0.102 * * \\
0.035^{* *}\end{array}$ & $\begin{array}{c}-0.059^{* *} \\
-0.215^{* *} \\
0.138^{* *} \\
0.053^{* *} \\
-0.023^{* *} \\
-0.068^{* *} \\
0.054 * *\end{array}$ & $\begin{array}{c}-0.061^{* *} \\
-0.201^{* *} \\
0.150^{* *} \\
0.040^{* *} \\
-0.022^{* *} \\
-0.051^{* *} \\
0.039 * *\end{array}$ & $\begin{array}{c}-0.069^{* *} \\
-0.206^{* *} \\
0.138^{* *} \\
0.047^{* *} \\
-0.011 \\
-0.032^{* *} \\
0.047^{* *}\end{array}$ & $\begin{array}{c}-0.096 * * \\
-0.214^{* *} \\
0.094^{* *} \\
0.035^{* *} \\
-0.032^{* *} \\
-0.049 * * \\
-0.010\end{array}$ & $\begin{array}{c}-0.093^{* *} \\
-0.211^{* *} \\
0.087^{* *} \\
0.052^{* *} \\
-0.012 \\
-0.039 * * \\
0.008\end{array}$ & $\begin{array}{c}-0.075^{* *} \\
-0.193^{* *} \\
0.111^{* *} \\
0.066^{* *} \\
-0.001 \\
-0.023^{* *} \\
0.003\end{array}$ \\
\hline
\end{tabular}




\begin{tabular}{|c|c|c|c|c|c|c|c|c|}
\hline Spouse working with no labor card & $0.023 * *$ & $0.012^{*}$ & $0.013 * *$ & 0.008 & $0.010 *$ & $0.020 * *$ & 0.006 & $0.020 * *$ \\
\hline Family total with labor cards & $-0.024 * *$ & $-0.019 * *$ & $-0.025 * *$ & $-0.025 * *$ & $-0.019 * *$ & $-0.030 * *$ & $-0.027 * *$ & $-0.023 * *$ \\
\hline Family total self-employed & $0.040 * *$ & $0.042 * *$ & $0.052 * *$ & $0.054 * *$ & $0.058 * *$ & $0.064 * *$ & $0.067 * *$ & $0.064 * *$ \\
\hline Family total number of children & 0.0006 & 0.0002 & $-0.0016^{*}$ & -0.0014 & 0.0005 & 0.0003 & -0.0002 & -0.0005 \\
\hline Family total number over 65 & -0.002 & -0.006 & -0.003 & -0.005 & -0.005 & -0.003 & -0.004 & $-0.008 *$ \\
\hline Other family earnings per head & $-.12 \times 10^{-7} * *$ & $-.31 \times 10^{-6} * *$ & $-.67 \times 10^{-5}$ & $-.83 \times 10^{-5}$ & $-.36 \times 10^{-6}$ & $-.14 \times 10^{-6}$ & $-.25 \times 10^{-5}$ & $-.38 \times 10^{-5}$ \\
\hline Sample size & 103,687 & 105,012 & 112,126 & 108,918 & 116,120 & 115,004 & 118,763 & 132,527 \\
\hline Log likelihood & -45028.3 & -45927.3 & -50127.6 & -52184.7 & -53936.2 & -52624.8 & -54372.8 & -61217.0 \\
\hline
\end{tabular}

Note: reported coefficients are marginal effects (which in the case of binary variables are for a discrete change in the variable)

* denotes $\mathrm{p}<0.05$; ** denotes $\mathrm{p}<0.01$; 
Table 10: Probit Estimates - Informal Activity

\begin{tabular}{|c|c|c|c|c|c|c|c|c|}
\hline & 1992 & 1993 & 1995 & 1996 & 1997 & 1998 & 1999 & 2001 \\
\hline Age & $-0.006 * *$ & $-0.006 * *$ & $-0.006 * *$ & $-0.007 * *$ & $-0.006 * *$ & $-0.006 * *$ & $-0.006 * *$ & $-0.004 * *$ \\
\hline Age squared & $0.00010 * *$ & $0.00010 * *$ & $0.00010 * *$ & $0.00012^{* *}$ & $0.00010 * *$ & $0.00010^{* *}$ & $0.00011^{* *}$ & $0.00009 * *$ \\
\hline Female & $0.065 * *$ & $0.051 * *$ & $0.060 * *$ & $0.057 * *$ & $0.058 * *$ & $0.044 * *$ & $0.045 * *$ & $0.055 * *$ \\
\hline $\begin{array}{l}\text { Ethnicity (reference: White) } \\
\text { Indigenous } \\
\text { Black } \\
\text { Asian } \\
\text { Mixed }\end{array}$ & $\begin{array}{c}0.065 \\
0.008 \\
-0.027 \\
0.002 \\
\end{array}$ & $\begin{array}{c}0.129 * \\
0.001 \\
-0.025 \\
0.004\end{array}$ & $\begin{array}{c}0.116 \\
-0.009 \\
0.013 \\
0.003 \\
\end{array}$ & $\begin{array}{r}0.040 \\
-0.012 \\
0.023 \\
-0.005 \\
\end{array}$ & $\begin{array}{c}0.219 * * \\
-0.008 \\
0.046 \\
0.004 \\
\end{array}$ & $\begin{array}{l}-0.004 \\
0.006 \\
0.023 \\
0.005 \\
\end{array}$ & $\begin{array}{c}-0.006 \\
0.002 \\
0.060 \\
0.010 *\end{array}$ & $\begin{array}{c}0.064 \\
-0.002 \\
0.026 \\
0.010 * * \\
\end{array}$ \\
\hline Illiterate & $0.024 * *$ & $0.041^{* *}$ & $0.041^{* *}$ & $0.028 * *$ & $0.046 * *$ & $0.039 * *$ & $0.052 * *$ & $0.073 * *$ \\
\hline $\begin{array}{l}\text { Schooling (reference: Elementary) } \\
\text { Primary } \\
\text { Secondary } \\
\text { College degree } \\
\text { Postgraduate degree } \\
\end{array}$ & $\begin{array}{l}-0.043^{* *} \\
-0.089^{* *} \\
-0.136^{* *} \\
-0.216^{* *}\end{array}$ & $\begin{array}{l}-0.035^{* *} \\
-0.079^{* *} \\
-0.150^{* *} \\
-0.238^{* *}\end{array}$ & $\begin{array}{l}-0.034 * * \\
-0.106 * * \\
-0.158 * * \\
-0.181 * *\end{array}$ & $\begin{array}{l}-0.041^{* *} \\
-0.101^{* *} \\
-0.153^{* *} \\
-0.170^{* *}\end{array}$ & $\begin{array}{l}-0.035^{* *} \\
-0.103^{* *} \\
-0.151^{* *} \\
-0.125^{* *}\end{array}$ & $\begin{array}{l}-0.035^{* *} \\
-0.097 * * \\
-0.154 * * \\
-0.198 * *\end{array}$ & $\begin{array}{l}-0.027 * * \\
-0.103^{* *} \\
-0.160^{* *} \\
-0.146 * *\end{array}$ & $\begin{array}{l}-0.029 * * \\
-0.119 * * \\
-0.173^{* *} \\
-0.151^{* *}\end{array}$ \\
\hline $\begin{array}{l}\text { Region (reference: South East) } \\
\text { North } \\
\text { Centre East } \\
\text { South } \\
\text { North East } \\
\end{array}$ & $\begin{array}{l}0.042 * * \\
0.014 * * \\
0.030 * * \\
0.073 * *\end{array}$ & $\begin{array}{l}0.047 * * \\
0.010^{* *} \\
0.031 * * \\
0.081 * *\end{array}$ & $\begin{array}{c}0.053 * * \\
0.007 \\
0.012 * * \\
0.072 * *\end{array}$ & $\begin{array}{c}0.052 * * \\
0.001 \\
0.005 \\
0.060 * *\end{array}$ & $\begin{array}{c}0.047 * * \\
0.001 \\
0.016 * * \\
0.068 * *\end{array}$ & $\begin{array}{c}0.046 * * \\
-0.010 \\
0.019 * * \\
0.064 * *\end{array}$ & $\begin{array}{c}0.019 * * \\
-0.012 * \\
0.009 \\
0.053^{* *} \\
\end{array}$ & $\begin{array}{c}0.039 * * \\
0.010 \\
0.016 * * \\
0.064 * *\end{array}$ \\
\hline Urban resident & $-0.014^{*}$ & 0.006 & $-0.023 * *$ & 0.0004 & 0.0002 & 0.0002 & $0.016 * *$ & 0.006 \\
\hline Union member & $-0.225 * *$ & $-0.227 * *$ & $-0.252 * *$ & $-0.219 * *$ & $-0.238 * *$ & $-0.229 * *$ & $-0.225 * *$ & $-0.224 * *$ \\
\hline Establishment $>11$ employees & n.a. & n.a. & n.a. & n.a. & n.a. & n.a. & n.a. & n.a. \\
\hline $\begin{array}{l}\text { Occupation (reference: Other) } \\
\text { Creative and technical } \\
\text { Administrative } \\
\text { Agricultural } \\
\text { Production and construction } \\
\text { Retail and distribution } \\
\text { Transport and comms } \\
\text { Domestic, personal and } \\
\text { catering services }\end{array}$ & $\begin{array}{c}-0.270^{* *} \\
-0.233^{* *} \\
0.451^{* *} \\
0.278^{* *} \\
0.480^{* *} \\
0.156 * * \\
0.596^{* *}\end{array}$ & $\begin{array}{c}-0.262^{* *} \\
-0.221^{* *} \\
0.463^{* *} \\
0.288^{* *} \\
0.488^{* *} \\
0.153^{* *} \\
0.605^{* *}\end{array}$ & $\begin{array}{c}-0.271^{* *} \\
-0.223^{* *} \\
0.434^{* *} \\
0.307^{* *} \\
0.483^{* *} \\
0.182^{* *} \\
0.571^{* *}\end{array}$ & $\begin{array}{c}-0.284^{* *} \\
-0.198 * * \\
0.417 * * \\
0.282^{* *} \\
0.447 * * \\
0.173^{* *} \\
0.564 * *\end{array}$ & $\begin{array}{c}-0.297^{* *} \\
-0.226 * * \\
0.421^{* *} \\
0.291^{* *} \\
0.440^{* *} \\
0.169 * * \\
0.565 * *\end{array}$ & $\begin{array}{c}-0.288 * * \\
-0.200 * * \\
0.438 * * \\
0.295 * * \\
0.449 * * \\
0.199 * * \\
0.562 * *\end{array}$ & $\begin{array}{c}-0.319 * * \\
-0.230 * * \\
0.414 * * \\
0.262 * * \\
0.417 * * \\
0.181 * * \\
0.557 * *\end{array}$ & $\begin{array}{c}-0.296^{* *} \\
-0.211^{* *} \\
0.406^{* *} \\
0.249^{* *} \\
0.403^{* *} \\
0.166^{* *} \\
0.539^{* *}\end{array}$ \\
\hline
\end{tabular}




\begin{tabular}{|c|c|c|c|c|c|c|c|c|}
\hline Spouse working with no labor card & -0.007 & 0.0003 & $-0.014 * *$ & -0.007 & $-0.014 * *$ & $-0.015 * *$ & $-0.022 * *$ & -0.008 \\
\hline Family total with labor cards & $-0.006 * *$ & $-0.006 * *$ & $-0.009 * *$ & $-0.009 * *$ & $-0.013 * *$ & $-0.012 * *$ & $-0.012 * *$ & $-0.008 * *$ \\
\hline Family total self-employed & $0.166 * *$ & $0.176 * *$ & $0.179 * *$ & $0.176 * *$ & $0.181^{* *}$ & $0.177 * *$ & $0.187 * *$ & $0.164 * *$ \\
\hline Family total number of children & $-0.019 * *$ & $-0.020 * *$ & $-0.020 * *$ & $-0.019 * *$ & $-0.019 * *$ & $-0.019 * *$ & $-0.020 * *$ & $-0.018 * *$ \\
\hline Family total number over 65 & $-0.017 * *$ & $-0.023 * *$ & $-0.019 * *$ & $-0.009 * *$ & $-0.024 * *$ & $-0.023 * *$ & $-0.017 * *$ & $-0.011 * *$ \\
\hline Other family earnings per head & $-.14 \times 10^{-8}$ & $-.17 \times 10^{-6} * *$ & $-.93 \times 10^{-5}$ & $-.11 \times 10^{-4} *$ & $-.74 \times 10^{-5}$ & $-.84 \times 10^{-5}$ & $-.44 \times 10^{-5}$ & $-.11 \times 10^{-4} * *$ \\
\hline Sample size & 103,700 & 105,031 & 112,127 & 108,924 & 116,120 & 115,011 & 118,767 & 132,534 \\
\hline Log likelihood & -44932.5 & -44995.1 & -48837.2 & -49312.3 & -51789.7 & -51760.3 & -53182.6 & -60935.2 \\
\hline
\end{tabular}

Note: reported coefficients are marginal effects (which in the case of binary variables are for a discrete change in the variable)

* denotes $\mathrm{p}<0.05$; ** denotes $\mathrm{p}<0.01$; 
Figure 1: Coincidence of alternative definitions of informality, 1992

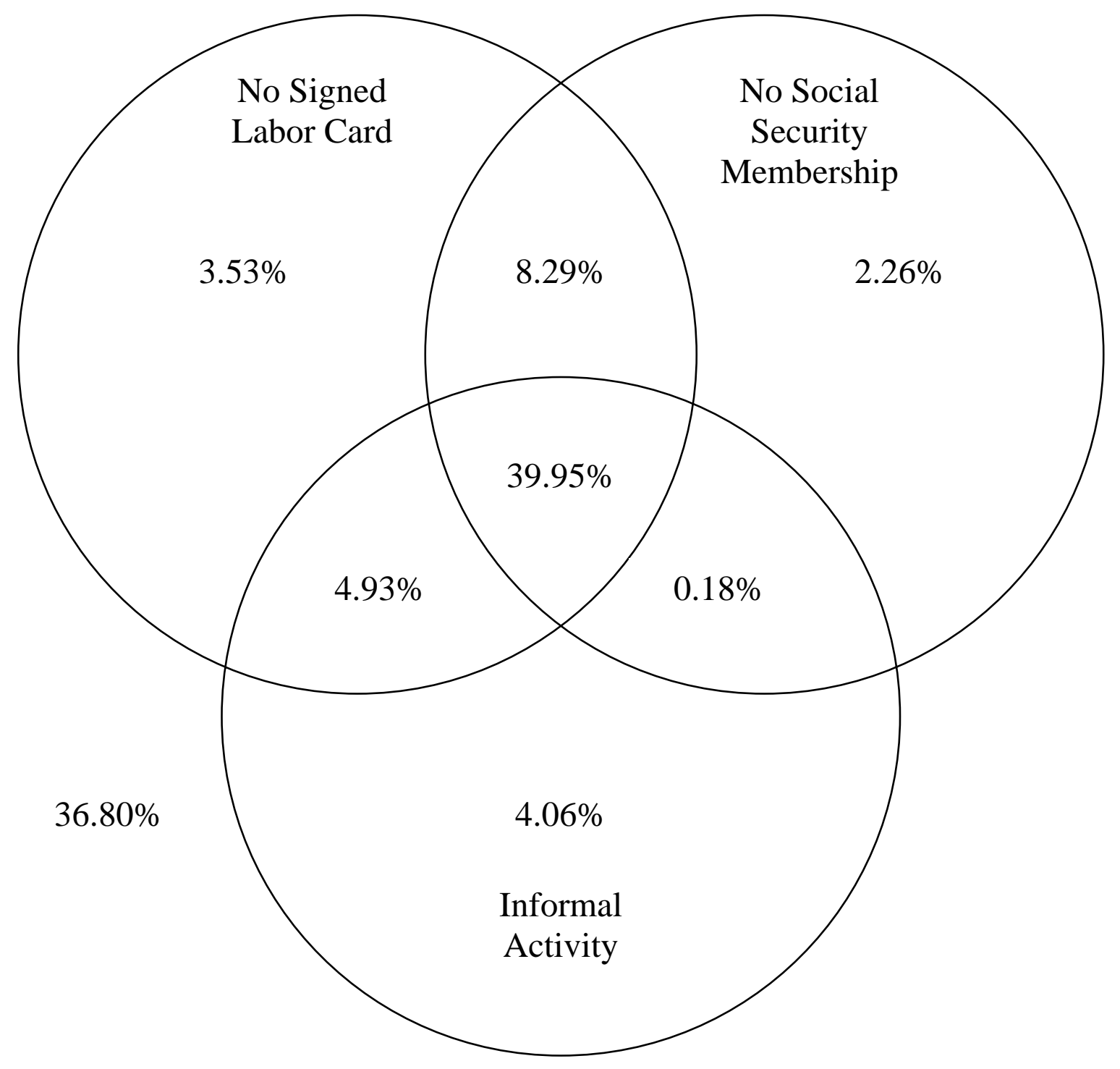


Figure 2: Coincidence of alternative definitions of informality, 2001

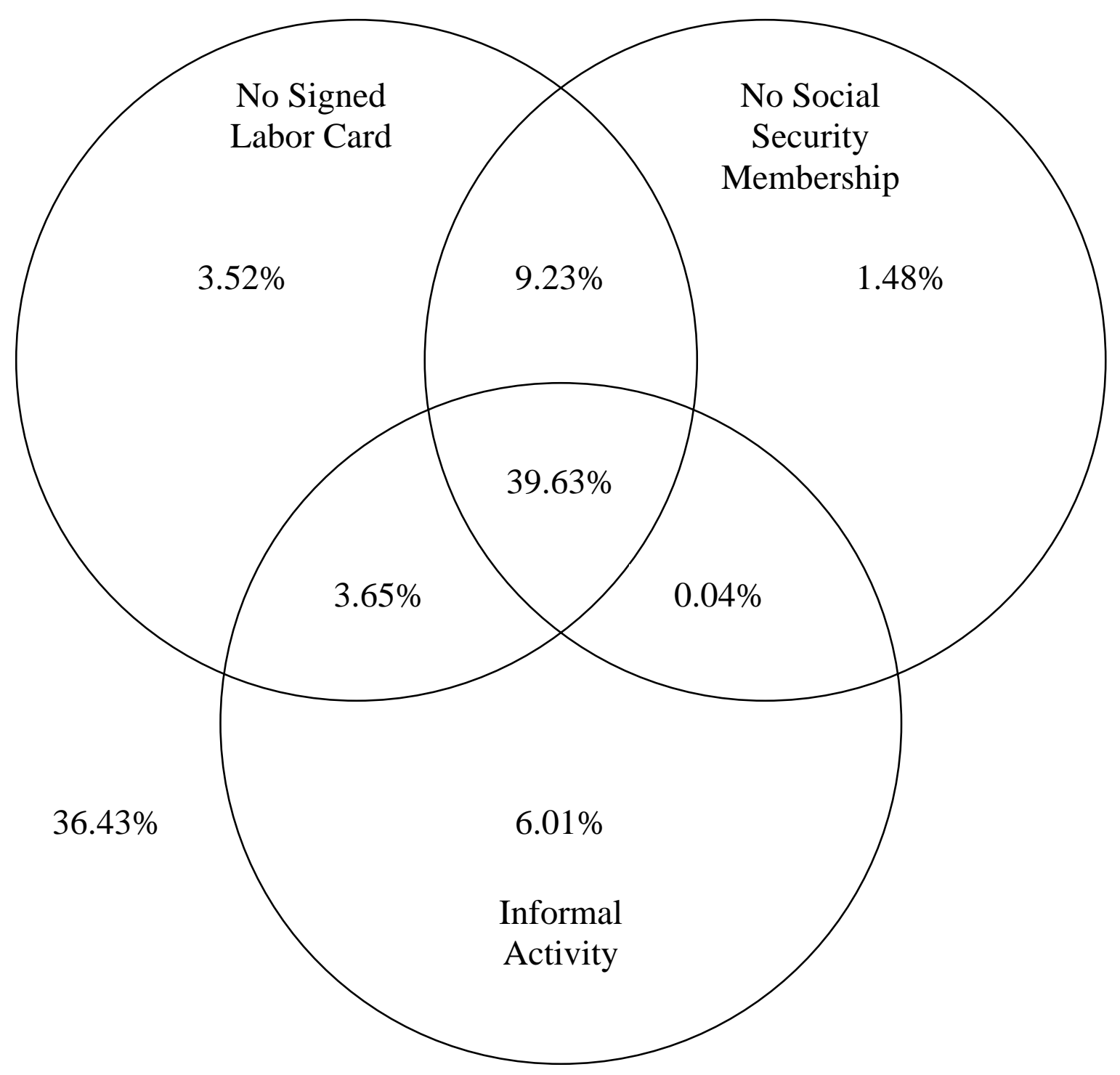

